\title{
Let the people decide: citizen deliberation on the role of GMOs in Mali's agriculture
}

\author{
Michel P. Pimbert ${ }^{1}$ (D) Boukary Barry $^{2}$
}

Accepted: 17 May 2021 / Published online: 7 June 2021

(c) The Author(s) 2021

\begin{abstract}
This paper describes and critically reflects on a participatory policy process which resulted in a government decision not to introduce genetically modified (GM) cotton in farmers' fields in Mali (West Africa). In January 2006, 45 Malian farmers gathered in Sikasso to deliberate on GM cotton and the future of farming in Mali. As an invited policy space convened by the government of Sikasso region, this first-time farmers' jury was unique in West Africa. It was known as l'ECID—Espace Citoyen d'Interpellation Démocratique (Citizen's Space for Democratic Deliberation) — and it had an unprecedented impact on the region. In this Deliberative and Inclusive Process (DIP), the ECID combined the citizens' jury method with indigenous methods for debate and dialogue, including the traditional African palaver. The ECID brought together male and female producers representing every district in the Sikasso region of southern Mali, specialist witnesses from various continents and a panel of independent observers, as well as resource persons and members of the national and international press and media. As an experiment in deliberative democracy, the ECID of Sikasso aimed to give men and women farmers the opportunity to share knowledge on the benefits and risks of GM cotton, and make policy recommendations on the future of GM technology in Malian agriculture. Designed as a bottom-up and participatory process, the ECID's outcomes significantly changed national policy on the release of GM technology and have had an enduring influence in Mali. In this paper, we describe our positionality as action researchers and co-organisers of the ECID. We explain the methodology used for the ECID of Sikasso and critically reflect on the safeguards that were put in place to ensure a balanced and trustworthy deliberative process. The ECID and its key outcomes are discussed in the context of the political economy of GM cotton in West Africa. Last, we briefly highlight the relevance of the ECID for current international debates on racism in the theory and practice deliberative democracy; the production of post-normal transdisciplinary knowledge for technology risk-assessments; and the politics of knowledge in participatory policy-making for food and agriculture.
\end{abstract}

Keywords African palaver $\cdot$ Citizens' jury $\cdot$ GMO $\cdot$ Agriculture $\cdot$ Biosafety policy $\cdot$ Democracy

\begin{tabular}{|c|c|}
\hline \multicolumn{2}{|c|}{ Abbreviations } \\
\hline AGRA & Alliance for a Green Revolution in Africa \\
\hline ARdS & $\begin{array}{l}\text { Assemblée Régionale de Sikasso (Regional } \\
\text { Assembly of Sikasso) }\end{array}$ \\
\hline $\mathrm{Bt}$ & $\begin{array}{l}\text { Bacillus thuringiensis, Refers to genetically } \\
\text { modified Bt cotton }\end{array}$ \\
\hline CMDT & Malian Textile Development Company \\
\hline
\end{tabular}

Michel P. Pimbert

michel.pimbert@coventry.ac.uk

Boukary Barry

boukarialatji@gmail.com

1 Centre for Agroecology, Water and Resilience (CAWR), Coventry University, Ryton Gardens, Wolston Lane, Coventry CV8 3LG, UK

2 Kene Conseils, ACI 2000, AV. Cheick Zayed, Bamako, Mali
DIP Deliberative and Inclusive Process

ECID Espace Citoyen d'Interpellation Démocratique (Citizen's Space for Democratic Deliberation)

CNOP The National Coordination of Peasant Organisations of Mali

GMO Genetically Modified Organism

ROPPA The Network of Peasant Organisations and Agricultural Producers in West Africa

USAID US Agency for International Development

\section{Introduction}

Mirroring its colonial past, West Africa today is at the receiving end of externally-led interventions designed to radically transform its food and agriculture (Schnurr 2015; 
Tsan et al. 2019; Agrilinks 2020). Peasant family farmers who represent the majority of agricultural producers in the region (Lowder et al. 2016) are expected to modernise by adopting genetically modified crops (Dowd-Uribe 2014; Rock 2018; Schnurr 2019; Luna 2020) and embrace technologies promoted by the Alliance for a Green Revolution in Africa (Patel 2013; Moseley et al. 2017; AGRA 2020) and the World Economic Forum (WEF 2018). In this context, the "issue of concern is who makes the choice of technology. Normally, the ones least affected by that choice are the ones responsible for determining that choice, while those forced to live with that technology have the least say in the matter" (Heyzer 1986, p. 7).

The absence of farmers' voices in decisions which affect their lives reflects deeply unjust power relations and a politics of exclusion that effectively silences a majority of men and women in rural West Africa. This democratic deficit in policy-making and technological choices is a global phenomenon that is widely acknowledged in the literature (Dryzek 2010; Fishkin 2011; Jasanoff 2016; Testart 2015; Pimbert 2018a).

In response to this democratic deficit, several actors in scientific and policy communities often place deliberative innovations such as citizens' juries, consensus conferences, deliberative polls, citizens' assemblies, and other such minipublics $^{1}$ at the centre of their hopes for deliberative and inclusive democracy (Pimbert and Wakeford 2001; Goodin and Dryzek 2006; Grönlund et al. 2015; Fishkin and Mansbridge 2017; Wironen et al. 2019; Campbell and Crittenden 2019; OECD 2020). However, it is noteworthy that surveys of peer-reviewed journal articles show that very few minipublics have been organised in the global South over the last twenty years (Wakeford et al. 2008; Elstub and Escobar 2019). Most research on mini-publics and deliberative processes focusses on Europe and North America (Goodin and Dryzek 2006; Smith 2009; Elstub and Escobar 2019). The African palaver as a form of consensus-building and conflict resolution based on dialogue as well as the deliberative methods used in Confucian, Islamic and indigenous cultures are either absent or under-represented in a largely westerncentric academic literature. This is problematic because democracy as deliberation and public reason is universal-it is not just a western construct (Sen 2003).

Moreover, the agendas of intersectional politics, antiracism, and decolonisation are rarely incorporated in the theory and practice of deliberative democracy and its politics of knowledge (Squires 2010; Martinez Palacios 2016). Uneven power relations persist, and continue to shape the

\footnotetext{
${ }^{1}$ Mini-publics are made up of small numbers of citizens, who may be self-selected or randomly selected from a larger population (Fung 2003).
}

minds, knowledge, and governance regimes of former colonial states (Ngugi 1986; Mignolo 2007; Mignolo and Walsh 2018; Fanon 2021). Modernity is thereby rendered as European and this maintains the ongoing erasure of colonised cultures, races, and knowledges in institutional and policy choices (de Sousa 2008; Bhambra 2014a; Bradley and Herrera 2016; Kelly et al. 2020). Enduring patriarchal relations also discriminate against women participating in decisionmaking (Goetz 1997; Hooks 2004; Federici 2012).

By and large, current mind-sets, epistemologies of knowledge, and governance regimes continue to be marked by these colonial, racist and patriarchal logics (Ngugi 1986; Crenshaw 1991; Dussel 1993; Scheurich and Young 1997; Grosfoguel 2007, 2011, 2013; Bhambra 2014a, 2014b; Mies 2014; de Sousa 2015; Bhattacharya 2017; Salleh 2017; Mignolo and Walsh 2018; Neajai Pailey 2019). For example, in a recent webinar several African citizens complained about how The Gates Foundation's complex web of funded relations and scientific networks works to exclude the knowledge of small and family farmers from national decisions on food and farming (CAGJ-AGRA Watch 2020). The disproportionate influence which this US-based foundation has on African agriculture was seen as colonial and inappropriate, particularly in the light of recently documented failures of AGRA projects funded by The Gates Foundation (Wise 2020). Overall, webinar participants echoed the more general view that "In Africa, the research agenda.... and 'given' conceptual frameworks should be continuously re-examined ... with the aim of eschewing all manifestations of new-colonial underpinnings and emphasizing indigenous ideas" (Ezeanya 2011, p. 10).

This paper describes and critically reflects on a participatory policy process which resulted in a government decision not to introduce genetically modified (GM) cotton in farmers' fields in Mali (West Africa). Most notably, the knowledge, analysis, priorities, and voices of Malian men and women farmers were at the centre of the deliberations that generated recommendations which changed national policy. Indigenous ideas also helped design the method used for this deliberative and inclusive process in Mali. As an invited policy space convened by the government of Sikasso region, this first-time farmers' jury was unique in West Africa. It was known as l'ECID-Espace Citoyen d'Interpellation Démocratique (Citizen's Space for Democratic Deliberation) on GMOs and the future of farming in Mali-and it had an unprecedented impact on the region.

Worldwide, the ECID of Sikasso is one of the very few mini-publics that has directly influenced policy making to date. Indeed, this positive example from Africa is "outnumbered by cases where a mini-public is established but turns out to have little or no effect on public decision-making" (Dryzek 2010, p. 170). 
This paper is written fifteen years after the ECID took place in January 2006, and we want to briefly explain why. As action researchers, we helped design the ECID and continue to be involved in follow up activities today. We wrote this paper in direct response to recent requests made by different actors in West Africa who have asked for detailed published information on the ECID's methodology and its overall design. This is because they wish to use the ECID's process-oriented methodology to facilitate citizen deliberations on two critical issues in their region:

i) Public health impacts of releasing genetically malesterile mosquitoes in the wild to reduce the transmission of malaria in Burkina Faso, Mali and the Ivory Coast. This biotechnology project is led by Target Malaria, a research consortium funded by The Gates Foundation and the Open Philanthropy Project Fund. Farmer and civil society organisations ${ }^{2}$ have asked for details on methods that could be used to design a transparent process of citizen deliberations on the risks and benefits of mass field-releases of GM male-sterile mosquitoes.

ii) Today's spiralling political conflicts, inter-ethnic and religious violence in Mali require bold approaches for conflict resolution and peace-building based on deliberative and inclusive governance (Yárnoz 2020). There is growing empirical evidence which shows that the use of minipublics and deliberative practices in deeply divided societies can enable recognition, mutual understanding, constructive social learning about the other side, and even solidarity across deep differences (O'Flynn 2007; Luskin et al. 2014). Several former members of the government of $\mathrm{Mali}^{3}$ have asked the authors to fully describe the methodologies used in the ECID of Sikasso for these reasons.

In this paper, we first briefly describe the context that gave birth to the ECID on GMOs and the future of farming in Mali. We also clarify our positionality as researchers and authors of this paper. Second, we describe in detail the methodology and process used to put the perspectives of African farmers at the centre of the ECID. Next, we critically reflect on the methodological safeguards that were put in place to ensure a balanced and credible deliberative process in which hitherto excluded actors had more voice and agency. Last,

\footnotetext{
2 The main organisations asking for methodological guidance are (i) CNOP - the National Coordination of Peasant Organisations of Mali; (ii) ROPPA - the Network of Peasant Organisations and Agricultural Producers in West Africa; (iii) COPAGEN - Coalition for the Protection of African Genetic Resources; (iv) IRPAD-Institute for Research and Promotion of Alternatives in Development.

3 Over the last 14 months, the former Malian Minister of Higher Education and Scientific Research (Dr. Assétou Samaké) and the former Minister for Territorial Administration and Local Communities (Dr. Ousmane Sy) have asked the authors for detailed information on the safeguards needed for balanced and trustworthy deliberations on sensitive issues.
}

we briefly analyse some of the ECIDs impacts on policy and practice.

\section{Context and positionality of researchers}

\section{National and regional context}

The ECID took place at a time when almost four million farmers were engaged in cotton farming in Mali, accounting for between 50 and $75 \%$ of the country's total export earnings (CMDT 2008). Income generation from the sale of cotton is linked to food security (Cooper and West 2016; FAO 2017).

Through the state cotton company (CMDT-Compagnie Malienne de Développement des Textiles or Malian Textile Development Company), the Mali Government controls all the key links in the cotton value chain. Since the early 2000s, the sector has been experiencing a crisis caused by a decrease in international cotton prices, lower yields, and difficulties in sector management. The CMDT, $60 \%$ of which is owned by the state and $40 \%$ by the French company DAGRIS, was losing money following the devaluation of the CFA franc and the collapse of the global cotton market, despite the fact that between 1994 and 2005 annual production rose from 320,000 to 600,000 tonnes (Forum pour l'Autre Mali 2004; Hugon 2005). Moreover, cotton production in Mali is causing increased environmental degradation, in large part owing to chemical inputs such as synthetic pesticides, increased tillage, and cotton's high nutrient demands (Moseley 2005). In Mali, cotton accounts for about $44 \%$ of all pesticides sold—with insecticides (52\%) being most widely used, followed by herbicides (31\%), then fungicides (10.8\%). The use of certain hazardous pesticides by small farmers has significantly increased risks to human health and the environment (Jepson et al. 2014; SAICM 2019).

It was in this context of crisis in the cotton industry that researchers from the Institut d'Economie Rurale in Mali proposed a five-year plan with the US Agency for International Development (USAID) to develop and commercialise GM cotton, starting with field testing in 2004 (GRAIN 2004). According to its proponents, a significant reduction in pesticide use would be enabled by genetically engineering into cotton plants the genes of Bacillus thuringiensis-a toxinproducing bacterium found naturally in the soil. The resulting GM cotton plants-so called Bt cotton-would produce Bacillus thuringiensis $(\mathrm{Bt})$ toxins that kill susceptible insect pests when they eat the plant (Tabashnik et al. 2003; Head and Dennehy 2010). Cotton yields were projected to increase with the reduction in pest-inflicted losses on Bt cotton (Purcell and Perlak 2004). Several peer reviewed articles pointed to the success of $\mathrm{Bt}$ cotton at reducing pesticide use and 


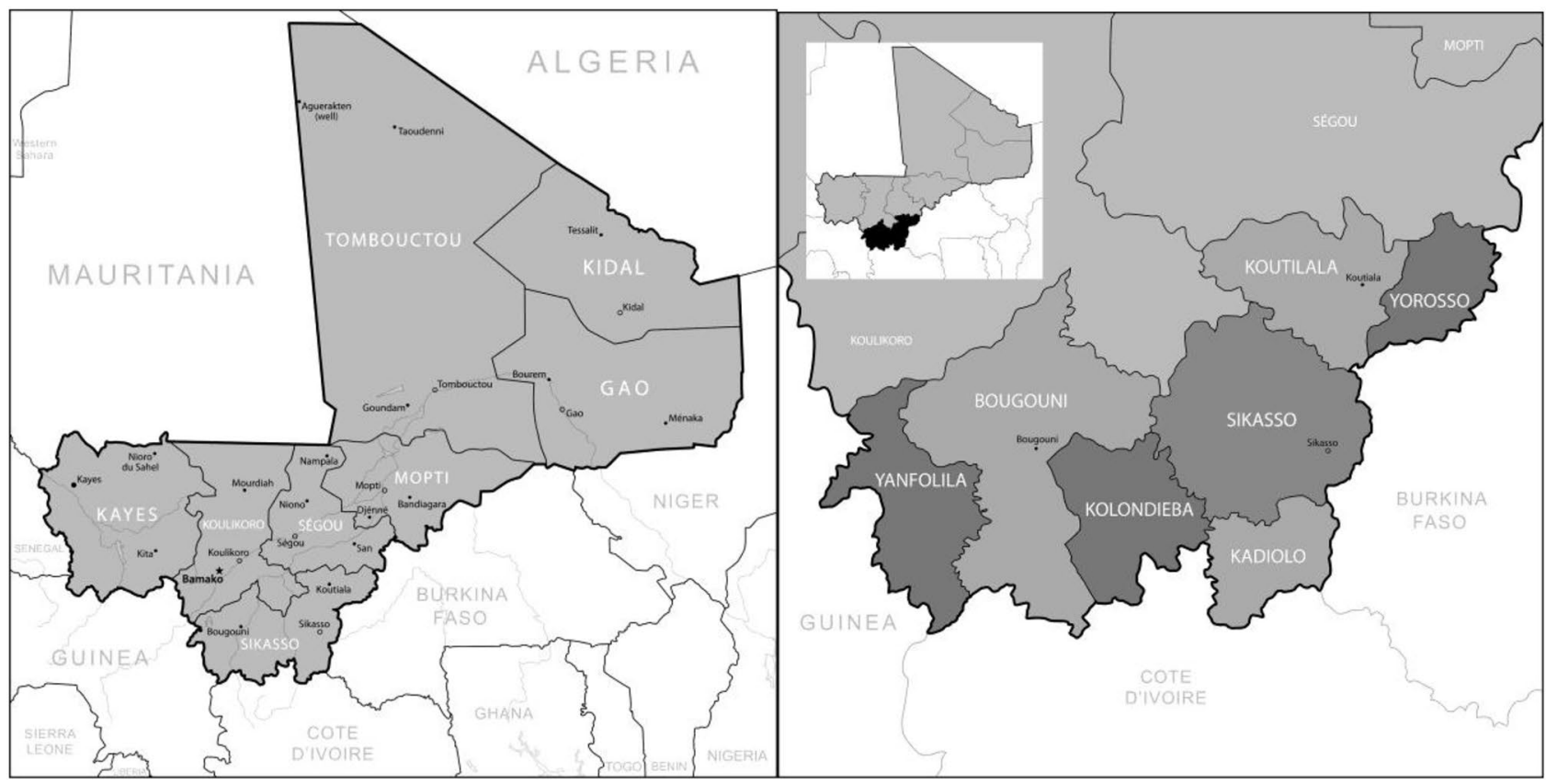

Fig. 1 Map of Mali (left) and districts in the Sikasso region (right)

increasing yields and profits for millions of smallholder producers in China, India, and South Africa (Pray et al. 2002; Qaim and Zilberman 2003 Morse et al. 2004).

Around the same time, global seed corporations had begun to actively shape the political economy of Bt cotton cultivation in Africa. South Africa authorised the commercialization of Monsanto's insect-resistant (Bt) cotton in 1997- the first GM crop in Africa. One year after its initial release, Monsanto launched a campaign to increase adoption of Bt cotton among smallholder farmers in the Makhathini Flats region in South Africa (Dowd-Uribe and Schnurr 2016). In 2003, the government of Burkina Faso signed a contract with Monsanto to test their insect-resistant Bt cotton in experimental field trials (Dowd-Uribe and Schnurr 2016; Luna and Dowd-Uribe 2020). Burkina Faso's biosafety law was enacted in 2006 and this greatly facilitated the field trials which led to the commercialisation of GM cotton in 2008 (Wafula et al. 2012). By 2010, about 80,000 farmers had planted Bt cotton on 260,000 hectares with an adoption rate of $65 \%$ (James 2010). More generally, public-private sector partnerships for biotechnology were part of a growing trend facilitated by international donors who brokered agreements between seed companies and government scientists to lease genetic material for use in Africa and promote GM crops throughout the continent (Wafula et al. 2012; Schurman 2017; Schnurr 2019). Major funders facilitating research and commercialization of GM crops in Africa include the U.S. Agency for International Development (USAID), the UK Department for International Development (DfID) as well as The Rockefeller and Gates Foundations (Rock 2018;
Russell 2018; Schnurr 2019). The discourse of these influential donors emphasises genetic engineering as a modernizing, poverty-relieving, humanitarian technology (Mittal and Moore 2009; Glover 2010; Schurman 2016). Inspired by former United Nations Secretary-General Kofi Annan's call for a uniquely African "green revolution", The Rockefeller and Gates Foundations founded in 2006 the Alliance for a Green Revolution in Africa (AGRA), which they continue to fund today.

As farmer organisations, citizens, and some local government officials became aware of plans to start field testing Bt cotton in Mali, there were growing calls for more information and a public debate on the impacts of GM technology on food and farming (ARdS 2005). Concerned citizens pointed out that whilst cotton production is mostly destined for the textile industry (cotton fibres), the oil produced by refining cottonseed is used for human consumption and thus contributes to food and nutrition. Most of the cooking oil used in Mali is derived from cotton plants and people were concerned that insecticide-producing Bt cotton could make cooking oil unfit for human consumption. ${ }^{4}$

In response to these public concerns, the ECID on genetically modified organisms (GMOs) and the future of farming in Mali was organised and held in Sikasso, from 25 to 29th January 2006. Sikasso is in southern Mali (Fig. 1), where

\footnotetext{
4 The majority of Malians buy cotton oil for cooking because it is about half the price of imported oils. However, there have been cases of human poisoning caused by adulterated and poor quality cooking oil (The New Humanitarian, 2008).
} 
cotton is the principal engine of economic development, generating benefits to farmers, rural communities, private traders, cotton companies and the national government (Tefft 2004).

The ECID of Sikasso aimed to give men and women farmers the opportunity to share knowledge on the benefits and risks of GM cotton, and make policy recommendations on the future of GM technology in Malian agriculture. It brought together 45 male and female producers representing every district in the Sikasso region (Fig. 1), specialist witnesses from various continents, a panel of independent observers, as well as resource persons and members of the national and international media.

\section{Authors positionality}

Our positionality is grounded in our experience of doing participatory action research (PAR) on agroecology and food sovereignty with indigenous and peasant communities in West Africa as well as Asia, Europe and South America. Over the last 30 years, we have accompanied and supported indigenous and peasant movements for food sovereigntyoften acting as listeners, catalysts, facilitators, advisors, mediators, co-producers of knowledge, and enablers who identify possible options for action by indigenous and peasant communities. As co-organisers and co-facilitators of the ECID we played all these roles at different times in the process which we describe and reflect on here.

Our positionality and praxis emphasise (i) humanizing relationships, deepening trust and building solidarity in research practices; (ii) power equalizing relations that value and enable non-academic agency in research; and (iii) transformative change that reverses the current democratic deficit in the production of knowledge and the governance of food and agriculture. Ultimately, our positionality reflects a commitment to a power-equalising process in which hithertoexcluded actors have more voice and agency to shape their life world(s) (Community Media Trust et al. 2008; Pimbert et al. 2017; Pimbert 2018a). Radically centring the excluded in knowledge creation and decision-making is vital in our theory of change: we see this as a site of transformative knowledge and resistance, as do other scholars working within anti-racist, anti-colonial, activist, and feminist traditions (Hooks 1994, 2000; Tuhiwai Smith 2012; Levkoe et al. 2018; Peoples' Knowledge Editorial Collective 2017; Hall and Tandon 2017).

We are committed to nurturing a democratic political culture, rather than simply developing supposedly ideal deliberative designs. Our deliberative democratic practice is motivated by a desire to open up multi-scalar social and political space for widespread critical scrutiny of expert knowledge and authorities by subalterns and excluded people. Fundamentally, our positionality reflects a commitment to allow deliberating "subjects to disrupt domination in its fullest sense, by contributing to a form of 'ongoing critical scrutiny' autonomous and reflective enough to resist and unmask the hegemony inherent in both specific authoritative acts and more general discursive structures" (Böker 2017, p. 10).

However, our positionality also embraces an allegiance to rigorous and credible transdisciplinary research. Ensuring the quality and validity of the knowledge and actions generated by the ECID were central concerns for us as coorganisers and facilitators. From the start we recognized that our values, subjectivity, and worldview could potentially influence our actions as researchers and our interpretations of events. We therefore tried to build strong safeguards into the ECID process to ensure it was generally credible, trustworthy, fair, and not captured by any interest group or perspective. We aimed for methodological rigour but we did not attempt to satisfy naïve notions of 'objective truth'. As action researchers our primary focus was to meet broader criteria of process validity-including inclusivity and quality of deliberation, diverse control, transparency, practical outcomes, empowerment, and enduring consequences (Bradbury and Reason 2001).

\section{Methodology: methods and process}

Action research was the distinct epistemological approach for our research and knowledge production (Reason and Bradbury 2013). It is methodologically distinct from other research approaches in that it explicitly aims to generate knowledge for action; recognises and values experiential, non-academic ways of knowing; and consciously contests hierarchies of knowledge (Fine et al. 2007). Within our iterative cycles of reflection, planning and action (Online Appendix Box A), we used specific methods and processes to co-produce, gather, analyse, and disseminate information.

\section{Methods}

This paper mainly draws on 15 months of action research conducted in Mali between May 2005 and July 2006. The crucial data for this paper comes from 106 interviews and recordings of the deliberations and palavers that took place during the ECID of Sikasso-including the preparatory process, the ECID's hearings, outcomes, and immediate policy impacts. The paper also includes some data gathered during further cycles of action research between 2006 and $2020 .^{5}$

\footnotetext{
5 During that 15 year period, we conducted a total of 364 interviews of cotton farmers, government officials, donor representatives, employees of non-governmental organisations, commercial seed companies, media professionals, and public and private sector researchers. These interviews are analysed in a forthcoming paper on the longterm impacts of the ECID. The ECID of Sikasso was one part of a multi-year participatory action research process still unfolding today.
} 
We used semi-structured qualitative interviews to triangulate and deepen our understanding of issues as they emerged during and after the ECID's deliberations. Interviews with farmers were mostly conducted in Bambara (the main local language which one of us speaks fluently). Triangulation of information was also aided through the analysis of daily audio and video film recordings of participants' comments, questions, answers, and deliberations. As participant-observers, we also drew on our personal research diaries and notes made during the ECID's hearings, field visits, workshops, and policy dialogues. We relied on methods for participatory learning and visualisation (Pretty et al. 1995; Salas and Tillmann 2010) as well as methods for Deliberative and Inclusive Processes (DIPs) (Pimbert and Wakeford 2001; Involve 2020) to facilitate social interactions, team dynamics, and the processes described next. Methods used to select farmerjurors are detailed in the Online Appendix.

Other organisers and participants in the ECID were not involved in the production of this paper; but they did provide comments and data which they validated and agreed to share with us for our analysis. ${ }^{6}$ The role of oversight panel members in validating our in situ analysis and choice of participant quotes included in this paper is described below. We combined our ethnographic observations with first-person inquiry (auto-ethnography) with audio and video recordings for a critical analysis of the data generated in the participatory process enabled by the ECID.

\section{The preparatory process: creating a democratic management structure}

A two-day workshop on 'GMOs and citizens' brought together regional councillors and representatives of farmer organisations, civil society organisations (CSOs), unions and technical services from the Sikasso region in June 2005. The workshop was convened by the elected regional government of Sikasso province-l'Assemblée Régionale (the Regional Assembly of Sikasso) (ARdS 2005).

The main outcome of the workshop was the decision to organise a public debate on the benefits and risks of GM cotton for farming in Mali. Participants agreed that citizen deliberations should take place under the auspices of the Regional Assembly. A multi-actor Steering Committee (SC) was set up to organise the deliberative process and included representatives from a diversity of public, private and civil society organisations as well as the President of the Regional Assembly (Online Appendix, Box B).

${ }^{6}$ Unless stated otherwise in this paper, the quotes from participants all came from the documentation of the ECID process, our personal notes, and our follow-up research interviews.
All organisations represented on the SC were from Mali except for two: the Réseau Interdisciplinaire de Biosécurité (RIBios-IUED ${ }^{7}$ in Switzerland) and the International Institute for Environment and Development (IIED in the UK). The Regional Assembly government of Sikasso had invited representatives of the RIBios-IUED and IIED to be part of the SC in order to provide conceptual and methodological support, and also to seek funding support (ARdS 2005). More specifically, the Regional Assembly (AR) and its President asked the co-authors of this paper to lead on the organisation of deliberations on GM cotton because we were both known to have extensive experience in designing and facilitating participatory processes. However, the government of Sikasso (AR) also expected to be closely involved in key decisions related to process and more strategic choices. Whilst we were asked to lead, our mandate was revocable at any time if the AR felt that activities were not aligned with the collectively agreed approach of the Steering Committee. Along with our positionality, this direct request from the AR was a key impetus for us and explains why and how we organised the deliberative process described here.

The entire SC agreed that the deliberative process should enable producers-men and women-to:

1. Better understand GMOs and their associated risks and benefits-particularly GM cotton in Mali.

2. Hear different viewpoints on the pros and cons of GM technology, and talk to experts on both sides of the GMO debate to reach an informed opinion.

3. Formulate policy and practical recommendations on the future role of GMOs in Malian agriculture.

To ensure flexible planning and timely implementation, the Steering Committee set up an Executive Committee (EC) that included the authors of this paper (Online Appendix, Box C). This EC was responsible for the logistical organisation and facilitation of the inclusive process. It was mandated to report back regularly and to discuss next steps with the larger Steering Committee.

Both the Executive and Steering Committees worked in an iterative manner through recurring cycles of reflection, planning and action to ensure that the entire deliberative process emerged in a flexible, responsive and adaptive manner (Online Appendix, Box A).

The EC established an independent Oversight Panel. Its role was to assess the credibility, fairness, competence and trustworthiness of the ECID process and its outcomes. The EC chose Oversight Panel members (Online Appendix, Box D) based on their reputation for integrity in Malian society

\footnotetext{
7 IUED: Institut Universitaire d'Etudes du Développement (University Institute for Development Studies).
} 
and government circles, their knowledge of deliberative processes, expertise in biosafety issues and risk assessments, gender balance and knowledge of African farming and rural development in Mali. This careful balancing act was guided by previous citizens' juries, and aimed to include a broad range of interests and perspectives without any one of them dominating (Coote and Lenaghan 1997). However, the panel was not so broad-based as to include potentially disruptive individuals opposed to the democratic accountability of corporations and governments.

Panel members included a majority of West African nationals and some Europeans with working experience in francophone Africa. Most notably, the panel was chaired by Mr Ousmane Sy who headed the Commission for Decentralization and Institutional Reform in Mali before serving as Minister for Territorial Administration and Local Communities in the national government.

During the preparatory phase, the Oversight Panel regularly discussed progress with the Executive Committee. Members were asked to review and validate key decisions as well as methods used (e.g. farmer-juror selection) and choices made (e.g. specialist witnesses). During the ECID itself, Oversight Panel members directly observed the proceedings, freely interacted with participants, and met daily with the organisers to comment on the quality of the process and suggest possible improvements to facilitation. At the end of each day of the ECID, the oversight panel members and the co-authors of this paper met and did an in situ analysis of participants comments by asking critical questions such as why a statement was made, by whom, how, and what was its impacts on the construction of collective knowledge. This daily participatory data analysis used logical reasoning and triangulation to gain crucial information from the ECID's hearings. The in situ analysis also allowed the oversight panel to validate the derived knowledge and its evidence base, as part of an extended peer review process. Agreements were reached on the most significant insights and comments made by farmer jurors, specialist witnesses, and oversight panel members. This analysis has guided the choice of specific quotes cited in this paper.

\section{Defining the methodology for a deliberative and inclusive process}

The ECID was the first ever deliberative technology assessment organised in West Africa. It combined two methodological innovations-one from Mali and the other from Europe and the USA.

The Malian method-the Espace Communal d'Interpellation Démocratique (CSDD or Communal Space for Democratic Deliberation) - is largely based on previous initiatives to discuss the strengths and weaknesses of the decentralisation process in the Sikasso region. During the 1990s, civil society groups worked with government officials to develop the CSDD to allow citizens living in the Sikasso's districts to call to account elected mayors and nongovernment organisations (NGOs) for any shortcomings in public services and other interventions. Prior to January 2006, two CSDDs had been organised in the Sikasso region (Centre Djoliba 2003). They had allowed many villagers to call out and question local mayors and NGOs on the misuse of funds and failures to deliver essential services (education, health, transport, water supply, public infrastructure development....). Lasting two to three days, these CSDDs primarily intended to facilitate a direct and frank dialogue between the local population and their elected politicians. Their main aim was to strengthen mutual listening and trust rather than frame policy recommendations or develop a position.

The Steering Committee members agreed that the local CSDD model was not entirely appropriate for a nuanced and inclusive deliberative process on GMOs and farming in Mali. For example, while the CSDDs were set up to call elected local officials to account, for a topic like GMOs questions needed to be answered by national and international experts (specialist witnesses) representing contrasting views from the public and private sectors, NGOs, farmer organisations, universities, etc. These specialist witnesses needed to be able to answer producers' questions and provide clear information on the benefits and risks of GMOs in food and farming — not only in scientific and technical terms, but also from a socio-economic, political, ethical and cultural angle. The CSDD model needed to be further refined to ensure a fair and meaningful debate on GM technology and its possible impacts.

The citizens' jury was identified as a useful process to combine with the CSDD approach. Developed in the early 1970s by the Jefferson Center in the United States ${ }^{8}$ and in Germany, ${ }^{9}$ the citizens' jury is a participatory action research method that involves between 8 and 20 non-specialist citizens who listen to and question specialist witnesses on a technical subject over the course of about five days. The witnesses present contrasting perspectives on the issue under debate and are cross-questioned by jurors, guided by one or more neutral facilitators or a chairperson. Unlike the CSDD, the citizens' jury does give a verdict and policy recommendations that are made public at the end of the deliberative process, usually in the form of a short report.

Elements of the local CSDD and the citizens' jury method were thus combined. The resulting methodological hybrid was called the Espace Citoyen d'Interpellation Démocratique (ECID—-the Citizens' Space for Democratic Deliberation). Further decisions about the methodological

\footnotetext{
${ }^{8}$ See: http://www.jefferson-center.org.

9 http://www.planungszelle.de.
} 
Table 1 Profile of farmerjurors selected for the ECID of Sikasso

\begin{tabular}{|c|c|c|c|}
\hline \multicolumn{2}{|l|}{ Initial selection criteria } & \multicolumn{2}{|c|}{ Actual participants } \\
\hline Type of farm & & Type of farm & \\
\hline A (large) & $15 \%$ & A & $17.8 \%$ ( 7 men and 1 woman) \\
\hline B (medium) & $35 \%$ & B & $33.3 \%$ (14 men and 1 woman) \\
\hline C (small, hand plough used) & $20 \%$ & $\mathrm{C}$ & $17.8 \%$ ( 7 men and 1 woman $)$ \\
\hline $\mathrm{D}$ (small, use of hand tool—the $d a b a$ ) & $30 \%$ & $\mathrm{D}$ & $28.9 \%$ ( 2 men and 11 women $)$ \\
\hline Overall gender balance (number of women) & $>30 \%$ & & $31.1 \%$ (14 women) \\
\hline
\end{tabular}

requirements for a rigorous, transparent and fair process to assess technological risks and associated development policies were informed by previous experiences with citizens' juries (Pimbert and Wakeford 2001; Pimbert et al. 2003; Goodin and Dryzek 2006). ${ }^{10}$

The African palaver was at the heart of the ECID, anchoring farmers' deliberations in a time-tested cultural and political tradition in Mali. Invented by Africans, the art of palaver is the most ancient form of governance and democracy (Diangitukwa 2014). Palaver style listening and discussion were encouraged during the ECID because this informal approach is relatively friendly, horizontal, pacific and generally open (Robert 2006). Organisers also felt that the palaver would enhance the quality and validity of the deliberative process because the "object of the palaver is the search for what is real, true and good for the community and for each of its members...It is a dynamic driven by a sense of community and seeking to preserve, restore and grow interpersonal communion" (Peeters 2020, p. 2).

\section{Ensuring an unbiased selection of farmer-jurors}

A total of 269 farmers were initially selected through stratified random sampling in all districts of the Sikasso region (Fig. 1). Additional criteria were then used to identify a total of 45 farmer-jurors from this random sample. Details of the selection process and methods used can be found in the Online Appendix.

After reviewing the entire farmer-jury selection process, the Oversight Panel validated the final composition of the ECID's panel of farmer-jurors. Overall, the profile of producers who participated in the ECID aligned well with initial quotas and selection criteria (Table 1).

\footnotetext{
${ }^{10}$ Citizens' juries have been used in the debate on GMOs in India, Brazil, Zimbabwe and the UK (Coote and Lenaghan 1996; Pimbert and Wakeford 2002; Pimbert et al. 2003; Wakeford and Pimbert 2003).
}

\section{Open framing of the ECID}

Recognising that there are situated knowledges and partial objectivities (Sundberg 2017), we were careful to allow the selected farmers to also frame the scope of the ECID. In the four months prior to the ECID, farmer jurors were able to decide on the framing of the ECID in each of the seven districts of the Sikasso region (Fig. 1). As co-facilitators of these discussions, we avoided narrowly concentrating on GM per se and encouraged farmers instead to discuss and locate the issue in the broader context of their own social, economic, and political concerns. These discussions by the farmer-jurors stretched the initial framing of questions on GM crops per se to include a consideration of impacts on the future of farming in Mali. Through this iterative participatory process (Online Appendix Box A), both farmers and Steering Group members agreed that the ECID should focus on 'GMOs and the Future of Farming in Mali'.

\section{Selecting specialist witnesses}

A crucial part of the ECID depended on identifying individuals willing and able to defend a particular vision of GM and farming futures in Mali. Specialist witnesses were invited to help inform discussions on GM cotton and its impacts on the future of farming. Their role was to clearly explain issues, present a viewpoint, advocate a position, summarise existing evidence and respond to questions asked by the farmer-jurors.

All specialist witnesses were formally invited by the President of the Sikasso Regional Assembly (AR) following Steering Committee recommendations. Each potential specialist witness was carefully briefed about the purpose of the ECID and their expected role. Specialist witnesses who agreed to participate in the ECID were asked to prepare a 45-min presentation to communicate their expertise in a clear and accessible manner to an audience of non-scientists. Specialist witnesses also had to agree in advance to answer any questions asked by farmer-jurors-both immediately after their public presentation and later if called back by the farmer-jurors to give further evidence or clarifications during the ECID. 
The names of specialist witnesses and the evidence they presented at the ECID on GMOs and the future of farming in Mali are shown in Box F (see Online Appendix). At no time were specialist witnesses allowed to interact and talk with farmer-jurors outside of the official hours for ECID hearings. ${ }^{11}$

\section{The process and outcomes}

The ECID hearings took place over five days between 25 and 29th January 2006, at the Centre Charles Langlois in Sikasso (Online Appendix, Box A).

Each specialist witness gave a presentation, which was followed by farmers' questions. ${ }^{12}$ As central actors in the ECID process, the farmer-jurors carefully listened to and interrogated the specialist witnesses. They weighed up the pros and cons of GM cotton on the basis of their own knowledge, new insights, priorities and aspirations. Men and women participants critically engaged with specialist witnesses, questioning them directly in plenary sessions. The 45 farmer jurors scrutinised the evidence and deliberated with each other in small groups (known as commissions) based on their gender and socio-professional status:

- Group A: Large-scale producers (7 people)

- Group B: Medium producers (14 people)

- Group C and D: Small producers (10 people)

- Women's only group: 14 women from all categories of producers.

This methodological innovation allowed for four parallel citizens' juries to run side by side during the ECID. Each commission thus acted as an enabling space for women and men farmers with different wealth and social status (small, medium and large producers). The African palaver (Diangitukwa 2014) was a key feature of the dialogical and deliberative processes in each commission.

Farmers were expected to work within their assigned commission and also to interact with members of other commissions during the ECID's plenary sessions. It was emphasised that the farmer-jurors' main role was to deliberate on

\footnotetext{
11 All specialist witnesses were housed in local hotels in Sikasso and all farmer-jurors slept in the hostel of the Centre Charles Langlois in Sikasso. These separate accommodation arrangements allowed the farmer-jurors to continue their palavers and deliberations in the evening without being interrupted or influenced by specialist witnesses. The latter were in a separate location for their overnight accommodation and they were asked not to interact with farmer-jurors outside of the ECID's formal hearings.

12 Written versions are available at the Regional Assembly of Sikasso, Mali.
}

what was best for everyone, and not just to represent themselves. The farmer-jurors were therefore asked to focus on discussing what would be best for all categories of cotton producers rather than just representing, say, small-scale or large-scale farmers.

\section{Facilitating the process}

Skilled facilitators were essential for facilitating the deliberations within the four commissions. The facilitators selected needed good local language and communication skills (in Bambara and French). Other important criteria included an ability to help people with contrasting backgrounds and life experiences to dialogue and work together, a sound knowledge of livelihoods and rural conditions in Mali, experience in village-level facilitation and conflict resolution, and representation of key sectors (government, academia and civil society). Five male and two female facilitators were sought to reflect the ECID's gender composition. ${ }^{13}$ In addition, two translators ${ }^{14}$ (French-English) made it possible for Englishspeaking specialist witnesses to participate in the event.

One facilitator was assigned to work with the same commission for the duration the ECID.

\section{The jury's verdict and recommendations}

Each commission was tasked with generating its own set of proposals and policy recommendations. The resulting sets of policy recommendations were shared and validated in plenary by all 45 farmer-jurors. The ECID's 'verdict' and policy recommendations of each commission are shown in Box 1.

The 45 farmers-jurors unanimously rejected the introduction of GMOs to Mali. An Oversight Panel member who is also a government expert on biosafety concluded:

“....democratic debates during the forum enabled us to find out what different producers think about the short-, medium- and long-term use of GMOs in Mali. This exercise clearly showed that there is widespread opposition among local farmers and civil society groups to the introduction of genetically modified crops, seed and products in Mali”. Mouhamadou Traoré.

The farmer-jurors' recommendations were delivered to the Sikasso Regional Assembly on 29 January 2006 (ARdS 2006). Whilst the recommendations made by the ECID were not binding, they proved extremely influential at the time. As

\footnotetext{
${ }^{13}$ Mrs Sanogo Djeneba Coulibaly, Mrs Fatoumata Kone, M. Boukary Barry, M. Abdoulaye Boniface Dembele, M. Lassana Touba Fofana, M. Richard Toe and M. Sogoba Bougouna.

${ }^{14}$ M. Abel Kone and M. Yacouba Kone.
} 
a direct result of the ECID, the government decided to indefinitely delay the approval of legislation that needed to be in place before GM crops could be introduced in Mali. ${ }^{15}$ This outcome was partly due to the fact that Mali is a signatory to the Cartagena Protocol on Biosafety. ${ }^{16}$ Under proposed legislation a public consultation was a pre-requisite at the national level before the introduction of any GMOs, even for testing. In this context, the ECID very clearly demonstrated the ability of farmer-citizens to contribute to policy-making processes.

\section{Box 1. Recommendations made by the four producers' commissions}

Commission A (large-scale producers)

- In view of the fact that $98 \%$ of producers in Mali operate on a small scale, and that GMO production techniques are only viable for large-scale producers, who account for just $2 \%$ of all farmers, we believe that this technology should not be introduced in Mali.

- Given that there are unused stocks of seed produced by our own researchers, and the possible unforeseen risks associated with GMOs, we recommend greater focus on unmodified seed rather than GMO varieties

- The lack of equipment and appropriate laboratories available to our researchers is another factor against the introduction of GMO plants

- Malian farmers will have to be trained in new technologies to enable them to manage their farms, so we oppose the introduction of any other foreign bodies that they are going to find hard to understand

- Organic cotton production is already ongoing and viable here in Mali. There is a market for it, it fetches a guaranteed minimum price, and it provides employment for women - so Bt cotton production should be halted, not encouraged

- As farmers, we believe that taking the gene from a nonnative animal and introducing it into a plant is contrary to our religious and social ethics

\footnotetext{
15 The ECID's recommendations were aimed at the Draft Bill on Biosafety of the Republic of Mali (2005).

16 Adopted as part of the Convention on Biological Diversity, the Cartagena Protocol on the prevention of biotechnological risk is intended "to contribute to ensuring an adequate level of protection in the field of the safe transfer, handling and use of living modified organisms resulting from modern biotechnology that may have adverse effects on the conservation and sustainable use of biological diversity, taking also into account risks to human health, and specifically focusing on transboundary movements". https://bch.cbd.int/ protocol/background. Accessed 17 January 2021.
}

\section{Commission B (medium-sized producers)}

- Research efforts should focus on developing and improving traditional varieties, not transgenic ones

- Producers should be involved in every stage of the research process

- The authorities need to work with producers on developing strategies to promote organic farming based on local products, and turn away from agri-chemical inputs

- The results of the ECID should be disseminated among rural umbrella organisations, the Regional Assembly, National Assembly, the Presidency and the media

\section{Commission $\mathrm{C}$ and $\mathrm{D}$ (small-scale producers)}

Our recommendations are made in the light of the various specialist witness presentations, our own concerns, the fact that certain major powers are resisting GMOs, and that some of our food products contain GMOs:

- No scientific research on GMOs should be undertaken in the name of Malian farmers as we are opposed to GMOs

- No research programmes on GMOs should be authorised in Mali

- A mechanism should be put in place to control and monitor imported foodstuffs to determine whether or not they contain GMOs

- The results of the ECID should be disseminated among all the authorities and officials across the country

- Arrangements should be put in place to share and report back on the results of the ECID at the local level.

Women's commission (includes every category of producer)

- Local seed varieties should be conserved so that they don't disappear

- Research should focus on local seed varieties

- The authorities should ban the introduction of GMOs in Mali

- The spread of GMO genes into our local varieties should be monitored and controlled

- Producers who persist in growing GMOs should have their crops burned, and the illicit production and distribution of GMOs should be punished

- The results of the ECID should be disseminated via publications and the media

- A mechanism should be put in place to monitor food products imported into Mali

- Techniques for producing organic sesame and cotton should be disseminated in every district in the region of Sikasso

-Women should be trained to produce organic sesame and cotton 
- Farmer Field Schools should be made available and accessible to more women

-Women should be involved in large forums and assemblies

The women farmers concluded by saying loud and clear:

"Yes to traditional seed varieties! No to GMOs! We don't want GMOs in Mali!"

\section{Process documentation and dissemination}

The whole ECID was recorded on digital video. The video archives provide a clear and accurate record of the event, including the location, the jury setting, the participants, the nature and quality of the debates, the process and its outcomes. The video archives were compiled to allow any party or external agency to check for possible shortfalls in balance, fairness or deliberative competence of the process. ${ }^{17}$

Members of the press were invited to document the hearings and outcomes of the ECID of Sikasso. The following national newspapers sent their correspondents to observe and report on the deliberative process: Les Echos and L'Indépendant, both from Mali; and Le Monde Diplomatique from France. A UK-based national newspaper, The Independent, covered the final day and the results of the ECID. Reporters and camera crews from national television in Mali were also present, returning three times to film and interview participants at the beginning, middle and end of the event. Reporters and technicians from seven community radio stations were present-one from each of the seven districts of the Sikasso region (Fig. 1). Local radio stations were also present each day and were closely involved in the ECID, recording and broadcasting both during the preparatory phase and the event itself. ${ }^{18}$

\section{Reflections on the quality and validity of the process}

Several safeguards were used to enhance the methodological rigour, trustworthiness, and transparency of the ECID.

\footnotetext{
17 The entire video archive is available from the Regional Assembly in Sikasso (Mali), the RIBios-IUED in Geneva (Switzerland) and the Centre for Agroecology, Water and Resilience at Coventry University (UK)

18 Radio broadcasts were heard by at least 1.7 million people in Mali's Sikasso region and also in some neighbouring districts of Burkina Faso and Ivory Coast (Daouda Mariko, URTEL, personal communication, April 2006). According to the 2009 census, the total population of the Sikasso region was 2,625,919.
}

\section{Diverse oversight and transparency}

The ECID of Sikasso focused on the risks and benefits of GM cotton in dryland farming. It was designed to explore a possibly dramatic transformation in the way cotton is produced and consumed — both as a fibre for the textile industry and as an oil for human consumption in Mali. The promotion of GM cotton as well as its real and imagined impacts were all highly controversial issues in that context. It was therefore crucial that this deliberative process was transparent and under the control of institutional actors with different vested interests, social aims and visions of agricultural development.

Four primary safeguard mechanisms were built into the ECID process with the explicit aim of enabling diverse control and transparency:

1. The Oversight Panel. The panel had an explicit mandate to assess the fairness, balance of plural perspective, and credibility of the ECID of Sikasso (see above). Chaired by a former government minister for Territorial Administration and Local Communities in Mali, the panel critically oversaw the entire process and systematically checked for possible biases and inconsistencies. The panel members shared their observations with the co-ordinating team at the end of each day of the farmerjurors' deliberations. They ensured that all parts of the process were continually evaluated by individuals with a diverse array of perspectives. The panel also made an overall evaluation of the ECID of Sikasso after the formal closure of the event.

2. The media observers and reporters. The semi-constant presence of the media thus ensured another level of control and vetting of the ECID process. The wide reporting of the event in the regional and national media highlighted the credibility and impartiality of the deliberations that generated important policy recommendations for Mali.

3. Multi-stakeholder observers. Several other observers were invited to witness the ECID process, on the understanding that they remain silent during the specialist witness presentations and the jury deliberations. These silent observers included other farmers from Mali and neighbouring Burkina Faso, NGO representatives, agricultural researchers, policy makers and planners, trade union representatives and corporate sector representatives. Whilst some stayed only two or three days, most witnessed the whole event and all developed opinions on the strengths and weaknesses of the process and were able to communicate their views to members of the oversight panel, the co-ordinating team and the press. Their presence further enhanced the transparency of the process. 
Fig. 2 An innovative, democratic and active extended peer review process

\section{Oversight and Extended Peer Review}

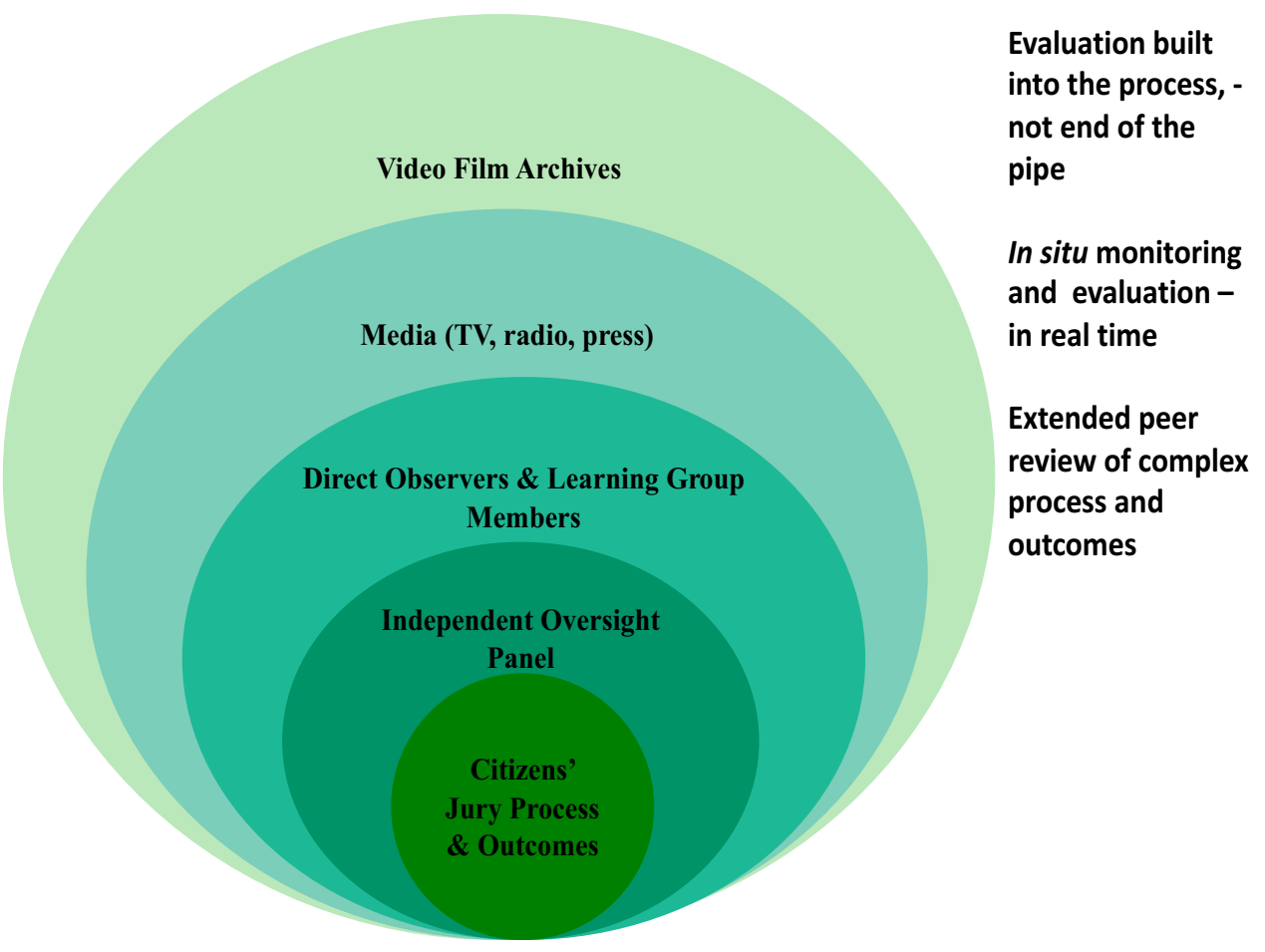

4. The video archives. These allow any interested party or external organisation to learn from this experience or check for possible bias, shortfalls in balance, fairness or deliberative competence of the process. ${ }^{19}$

Diverse oversight and transparency were thus built into the very design of the ECID of Sikasso. Moreover, control over and scrutiny of the unfolding dynamics of the ECID took place in real time and in situ. This multi-level scrutiny of the ECID (Fig. 2) allowed different participants to co-construct their own knowledge and contest the validity of that of others in an open deliberative arena. Most notably, the independent Oversight Panel members acted as an extended peer review community that was able to directly witness the dynamics of knowledge production and policy formulation. The Oversight Panel had the power to decide which methods and processes (representativeness of jury, balance of witnesses, quality of facilitation...) were appropriate and what constituted valid knowledge in that context.

\footnotetext{
19 The video recordings also show what the ECID's deliberations actually looked like. Filmed over 5 days, this archival video footage allows viewers to see the types of evidence presented by special witnesses, the kinds of questions jurors asked, and how groups deliberated amongst themselves. Additional video footage on what the process and outcomes of the ECID can be accessed in an ethnographic film shot during the hearings-Senekelaw Ka Kuma. Paroles de Paysans. https://youtu.be/-4E2LGNneBQ. Accessed 12 December 2020.
}

Commenting on the quality of the deliberative process and its outcomes, the Chair summarised the opinion of the oversight panel members:

" The steering group undertook the preparations for the ECID of Sikasso in a neutral, balanced and professional manner. Protagonists showed respect for each other's opinions during a healthy exchange of views. There was a free and responsible debate on a matter of strategic importance for the future of Malian agriculture". Ousmane Sy.

This innovation for extended peer review and oversight (Fig. 2) sought to decentralise and democratise the production and validation of knowledge as well as ensure that the outputs of the ECID were as legitimate and representative as possible. The oversight panel's in-situ verification of facts and real-time assessment of the quality and validity of the ECID advanced the practice of post-normal science and knowledge democracy (Funtowicz and Ravetz 1993; Benessia et al. 2016; Pimbert 2018b). Post-normal science recognises that in a fast-changing world the facts are uncertain, values are often in dispute, stakes are high and decisions are urgent. Its core ideas include an 'extended peer community' and the recognition of a diversity of legitimate perspectives to construct and validate knowledge on every issue (Ravetz 2006). 


\section{Diverse control and funding}

Diverse control was also ensured in the ECID of Sikasso by relying on different sources of funding. Funding for the ECID of Sikasso mostly came from two donors who each contributed close to $90 \%$ of the total budget:

- the Swiss Agency for Development and Cooperation (SDC), Switzerland

- the Dutch Ministry of Foreign Affairs (DGIS), The Netherlands

The Regional Assembly and other Malian partners involved made a small financial contribution (10\% in total). However, they made important non-monetary donations and human contributions which were decisive in ensuring strong control over the ECID by locally and nationally accountable organisations.

The ECID took place under the auspices of the Regional Assembly of Sikasso, which is an integral part of the Mali Government. In this sense, the ECID was an invited policy space that was created and opened up from above by the government, rather than from below on the initiative of citizens (Cornwall 2004; Cornwall and Coelho 2006). There was therefore a risk that the Regional Assembly might unilaterally steer the process in its preferred direction and towards its favoured policy outcomes. This has indeed been a common practice in Europe where governments have organised large-scale consultations and deliberative participatory processes on GM technology (Dryzek and Tucker 2008; Levidow 2008; Levidow and Carr 2009; Aasen and Vatn 2013). Some of these policy spaces commissioned and created from above ended up closing down debate and/or co-opting mini-publics. ${ }^{20}$ However, it is noteworthy that the Regional Assembly of Sikasso respected inclusive decision making and democratic control within a Steering Committee made up of very different institutional actors (Online Appendix Box B). At no time did this regional government attempt to take over the process, impose its views or censure critical and potentially subversive opinions in the ECID. This positive outcome was partly due to the President of the Regional Assembly's clear commitment to democratic

\footnotetext{
${ }^{20}$ Commissioning governments have often co-opted and trivialised deliberative processes when they create opportunities for agency and participation in policy making. In the late 1990s', the UK government's much-publicised experiment in deliberative democracy ended up being condemned by its own Parliamentary Committee as "closer to market research than public consultation" (Irwin 2001, p. 74). In the environmental field too, available evidence indicates that there are strong dangers of co-option of green ideas and jury recommendations by the State (Dryzek 2000). There is always a danger for democracy when too much agenda-setting power is given to those who commission mini-publics.
}

values, and partly because relatively powerful producer organisations were represented on the Steering Committee (Online Appendix Box B). The principle of diverse control was thus enshrined and adhered to in the overall governance of the ECID of Sikasso.

\section{A diversity of specialist witnesses}

The diversity of witnesses ensured that key sectors of society-government, farmer trade unions, civil society organisations, business and research institutions -, contributed a broad range of views on GMOs and the future of farming in Mali (Online Appendix Box F).

Members of the Oversight Panel seemed satisfied that the specialist witness presentations effectively reflected the views of their different constituencies:

Dr Mouhamadou Traore: "Expert witnesses with highly divergent views on GMOs were invited to attend the forum. The themes presented by these expert witnesses gave participating producers access to contradictory information on GMOs. As a result, expert witnesses and producers were able to engage in meaningful debates."

Mohamed Haidara: "The methodology has allowed opinions in favour and against GM cotton to be fairly presented and properly debated during the ECID". Danielle Bütschi: " ....the ECID was a balanced forum, giving GM supporters and detractors equal opportunities to air their views, particularly during the expert witnesses' presentations. In quantitative terms, a perfect balance was achieved".

However, a few institutional actors declined the invitation to participate in the ECID. The absence of these key specialist witnesses meant that some arguments in favour of particular models of agricultural development may not have been represented as well as they could otherwise have been. The non-appearance by the following four organisations is especially noteworthy:

- Monsanto Company, an agrochemical and agricultural biotechnology corporation based in the USA, ${ }^{21}$ which is a major promoter of GM cotton seeds in West Africa. ${ }^{22}$

- Syngenta Foundation for Sustainable Agriculture, a nonprofit organisation linked to the global company Syngenta AG that conducts genomic research and produces agrochemicals and seeds. Syngenta Foundation's mission

${ }^{21}$ In 2018, Monsanto company was acquired by the German multinational Bayer AG as part of its crop science division.

22 Whilst Monsanto declined our invitation it did recommend a farmer who supported and promoted its technology: TJ Buthelezi. A Zulu farmer from South Africa, Mr Buthelezi had been growing $\mathrm{Bt}$ cotton since 1996 and agreed to be a specialist witness who would share his experience as a GM cotton farmer. 
in Mali is to help farmers access quality, affordable seeds of improved crop varieties.

- DAGRIS (formerly CFDT and now GEOCOTON) is a major industrial operator with a fully integrated cotton value chain and a business partner to the biggest cotton companies in West Africa, including Mali's CMDT.

- USAID, an international development agency and a catalytic actor which promotes genetically engineered crops in West Africa. ${ }^{23}$ Prior to the ECID of Sikasso, the Government of Mali received much of its advice and funding from USAID for the development of biosafety regulations for GMOs.

Despite several Regional Assembly invitations ${ }^{24}$ sent to headquarters and national representatives of these organisations over a period of several months, Monsanto Company, Syngenta Foundation, DAGRIS and USAID were unable to participate in the ECID of Sikasso. In some cases, organisers suspect they were rather unwilling to engage in this deliberative process. In other cases, reasons for not taking part were made crystal clear to the organisers. For example, Syngenta Foundation did not authorise its chief scientist and representative in Mali to give evidence as a specialist witness because, "We are not going to participate in something we cannot control" (Dr Andrew Bennett, Director of the Syngenta Foundation for Sustainable Agriculture). In a previous mini-public (Prajateerpu) in which Syngenta was specialist witness, its GM vitamin A rice was rejected by a jury of small Indian farmers in 2001 (Kuruganti et al. 2008). The ensuing negative international publicity for Syngenta may explain why it's Foundation decided not to participate in the ECID. More generally, evidence shows that corporate actors such as Syngenta, DAGRIS, and Monsanto have a long track record of controlling the discourse and limiting debate on policy and technology choices (Pio 2007; Nipon et al. 2017; UCS 2017; Marks and Paravacini 2018; Monsanto Tribunal 2016; Luna and Dowd-Uribe 2020).

\footnotetext{
23 https://www.usaid.gov.

24 The ECID was done under the auspices of the regional government of Sikasso (Regional Assembly-AR). It was a policy space opened up from above, and as such the ECID was seen to be legitimate and trustworthy by most actors.
}

\section{Creating safe spaces}

The ECID was conceived as a safe space for communicative action (Habermas, 1981) in which reflection and co-operative action could be carried out by individuals on the basis of deliberation and argumentation in a carefully thought-out environment of mutual support and empathy. Within these spaces, people who might feel threatened or vulnerable by sharing their knowledge and experience could gain confidence, analyse, question, organise and act.

However, the possibility that patriarchal relations, hierarchy and self-censorship might constrain deliberation and inclusion was a genuine concern for the organisers of the ECID. A common observation in many participatory processes, especially those undertaken where there are pronounced social hierarchies, is that men and wealthier individuals are generally far less inhibited about contributing to debates than women and poorer people (Hill Collins and Bilge 2020). With a relatively large group of 45 farmerjurors there was also a risk that more introverted, quieter or less confident individuals might be marginalised and even excluded from discussions.

These risks were minimised by setting up the separate and smaller commissions based on farm size and gender (Table 1 and Box 1). This safeguard created protective spaces that reduced possible intersectional and gender discrimination.

It is noteworthy that about $20 \%$ of the male farmer-jurors were initially not comfortable with the participation of women. At the start of the ECID, some men were heard saying "This is not the place for women" (Mamadou) ${ }^{25}$ and "Women cannot sensibly discuss technical issues like GM science and its benefits" (Abdoul). The all-women commission allowed women-who were mostly small marginal farmers (Table 1) - to freely express their own views without being subjected to gender discrimination and male chauvinism. By the end of the ECID, the women farmers not only generated their own recommendations (Box 1), they also gained the respect of the initially prejudiced men. On the last day the men noted: "We are proud of our women. They debated so well and had many good ideas" (Mamadou and Abdoul). "Their recommendations are so bold and very relevant for the future of family farming in Mali" (Ibrahim and Mohammed).

These safe spaces for male and female producers helped resolve differences among farmer-jurors as well as co-ordinate diverse interests within and between commissions. By embracing these politics of difference, the ECID of Sikasso thus respected the dignity and the agency of differently positioned farmer-jurors by "giving political representation to

\footnotetext{
${ }^{25}$ Farmer-jurors are identified only by their first name to respect their privacy and the confidentiality of the information made public.
} 
group interests and celebrating the distinctive cultures and characteristics of different groups" (Young 1986, p. 22).

The four commissions co-existed and functioned as relatively independent and parallel citizens' juries within the ECID. In their palavers, each commission was able to develop its own ground rules (e.g. no interrupting, giving every participant equal opportunities to speak, etc.) with the help of their facilitator. While this led to some differences in the way that the different arguments and recommendations were formulated in each commission, it was felt this approach was necessary to ensure a genuinely participatory process. It also added a further empowering dimension to the ECID by facilitating a diversity of approaches in each commission that allowed for a wide range of viewpoints and arguments to be expressed. The different commissions thus offered a safe space that allowed farmers "to explore their intersubjectivity and construct shared meanings that made sense to them" (Jean Luc Virchaux, Oversight Panel member).

A further indication of the quality of these safe spaces was the extent to which the farmer-jurors were allowed to interrogate their sources of information, rather than simply being passive recipients of specialist testimonies. The proportion of time that was devoted to the presentation of witness evidence versus the amount of time allowed for interrogating witnesses was roughly equal $(50 \mathrm{~min})$. According to the Oversight Panel, this appeared to be enough for the jurors to become sufficiently informed about the issues on which witnesses gave evidence. This compares favourably with other similar processes (Pimbert and Wakeford 2001, 2003). The length of this interrogation period also allowed jurors to draw on their own experience to challenge the 'facts' and arguments made by the specialist witnesses.

Moreover, farmer jurors had another opportunity to directly interview witnesses by recalling them to give more evidence in the safe space of their respective commissions. A total of 7 specialist witnesses were invited by the different commissions to give more detailed information and clarifications. For example, Dr Siaka Dembele was invited by the medium and large producer commissions to clarify what his research institute had agreed with Syngenta and Monsanto about the use of $\mathrm{Bt}$ genes in cotton in Mali. During this exchange with Dr Dembelé, farmers learnt that Mali, as a low income country, did not have adequate lab equipment and facilities to ensure proper biosafety for GM research. Further discussions between Mr T. Buthelezi and the commission of small-scale producers revealed that Bt cotton seed is three times more expensive than hybrid cotton seed in South Africa. All commissions re-invited the Indian farmer witnesses for more details on how insect pest attacks had led to the failure of $\mathrm{Bt}$ cotton cultivation and subsequent farm bankruptcies in parts of Andhra Pradesh (AP). As members of the Community Media Trust, both women farmers had made two films on the impacts of Bt cotton on farmers lives in Warangal district (AP). The commissions learnt about the many farmer suicides and human tragedies associated with Bt cotton failures in Warangal district where close to 1 million people live. ${ }^{26}$ Finally, the women's commission called back Dr Hama Garba to ask him how women could become more involved in farmer field schools and agroecological approaches to control pests. The ECID allowed the farmerjurors to not only scrutinise the evidence. It also provided them with opportunities to challenge the manner in which witnesses had framed the issues.

Compared with the farmer-jurors, most specialist witnesses were wealthier, better educated, often urban-based, and represented powerful organisations. Despite these unequal power relations and asymmetrical relationships, interactions between specialist witnesses and the jurors were mutually respectful. However, inequalities did surface in a few instances. At times the farmer-jurors reported feeling undermined by what some specialist witnesses said or implied. When the Director of the Agricultural Production programme of Burkina Faso argued that people should not worry about pesticide poisoning because their bodies can adapt to and neutralise toxic pesticides, the farmer-jurors could tell this was fake science. Nevertheless, several men and women holding babies in their arms were distressed and momentarily destabilised by the arrogance and callousness of this specialist witness. ${ }^{27}$ Power relationships between insensitive technocratic witnesses and farmer-jurors were played out during some of the ECID's hearings.

Overall however, the relationships were sufficiently enabling and non-hierarchical for farmer-jurors to participate meaningfully in debates on GMOs and the future of farming

\footnotetext{
${ }^{26}$ A citizen-led study carried out over a period of three years chronicles the fraudulent promises of the industry and the impacts of $\mathrm{Bt}$ cotton in Warangal in Andhra Pradesh (AP). This three-year study of Bt cotton was initiated by the AP Coalition in Defence of Diversity and the Deccan Development Society. The study, Bt Cotton in Andhra Pradesh: A Three Year Assessment, was published in 2005. The film made by the two Indian women farmers-Bt Cotton in Andhra Pradesh: A three year fraud - was part of the study and captured the more qualitative dimensions of the crisis experienced by farmers. The film brings alive the voices and images of farmers who tried to grow Bt cotton-stories of terrible loss, pain, and anger, leading to violence and even death. The second film made by the Indian women farmers involved in the ECID's hearings was called Why are Warangal farmers angry with Bt Cotton? This film also shows how after its introduction in 2002 in Warangal District, Bt cotton brought in its wake misery, destruction and death, particularly among small and marginal farming families (see films in Community Media Trust et al 2008). During the ECID's hearings, the Indian women farmers only spoke about the context they knew of in AP. They were careful not to extrapolate their findings from Warangal (AP) to the rest of India where farmer suicides are high but sometimes contested and unevenly spread across Bt cotton growing States (Flachs 2019).

27 See for example footage from the video film Senekelaw Ka Kuma. Paroles de Paysans-from 43.40 to $44.16 \mathrm{~min}$. https://youtu.be/4E2LGNneBQ. Accessed 15 December 2020.
} 
in Mali. In his report written at the end of the hearings, the Chair of the Oversight Panel noted:

"Conflicting views were expressed in a way that respected differences of opinion or position. Participants formed an opinion and came away with the ability to make a judgement about public policy". Ousmane Sy

\section{Reflections on the views of farmer-jurors}

The African palaver tradition was at the heart of the farmers' deliberations, giving the ECID of Sikasso its unique character, rhythm, and dialogical quality. As a participatory, inclusive, and open-ended process that took into consideration each person's contribution, the ECID palavers embraced an integrated perspective which focussed on the whole situation, in all of its aspects.

Without exception, all four commissions were opposed to the introduction and cultivation of GM cotton in Mali (Box 1). However, the recommendations made by each commission were diverse and nuanced, reflecting different primary reasons for rejecting GMOs.

Large-scale farmers strongly emphasised ethical and equity concerns in their recommendations (Box 1, Commission A). They pointed to how divisive new GM seeds would be in their villages as poorer farmers would not be able to buy them. Whilst deliberating, members of this commission voiced real concerns about impacts on social peace and livelihoods:

"If I have a GM cotton field and my neighbour doesn't, contamination problems are bound to create conflict between us." Abdul.

"What's the point of encouraging us to increase cotton yields with GMOs when we can't get a decent price for what we already produce?" Kone.

Medium and small-scale farmers were unanimous in strongly recommending greater farmer control over agricultural research. They particularly emphasised the need for producers to be involved in every stage of the research process. Many observers in the ECID were surprised by the family-farmers' sophisticated understanding of the pivotal role of agricultural research in developing (or not) GM technologies. Farmers called for more democratic control over research to ensure that it meets the needs identified by family farmers (Box 1, Commissions B, C and D). In many ways their recommendations anticipated today's current debates on the need to democratise food and agricultural research (Pimbert 2018b; www.excludedvoices.org) to develop appropriate innovations for family farming (FAO and IFAD 2019).
The recommendations of the all-women commission emphasised the need to preserve local seed varieties and traditional know-how. It is noteworthy that the women family-farmers framed issues and recommendations in a more holistic way, emphasising the multiple functions and benefits of agriculture. After the women's commission had recalled the specialist witness from South Africa (Mr Buthelezi) for further questioning, a member said:

"If a producer tells me he is earning a lot by growing GM cotton, I am happy for him. But as far as I am concerned, I cannot ignore the consequences of GMOs on the soil and the environment. I do not just want to make money. I want to look after my own and my family's health, as well as the health of my country and even the whole world". Alimata. ${ }^{28}$

The recommendations made by the women's commission also identified alternatives to GM technology, including local seeds, greater support for organic cotton and sesame cultivation, and women training in agroecology through farmer field schools (Box 1).

Throughout the ECID, the women family-farmers articulated and brought together concerns about preserving the environment and the renewal of life, properly rewarding their contributions to farm labour, and recognising the importance of their reproductive labour in family farming. Women farmers were, in some cases, more outspoken than male farmers about taking radical action to defend life:

"We don't want GMOs, ever", said Lidigoita, "and we are calling upon the government to prevent them entering the country. If farmers grow them illegally, we'll set fire to their fields."

This view was expressed by one member of the women's commission after hearing witness evidence from Indian women farmers on high suicide rates associated with $\mathrm{Bt}$ cotton cultivation in Andhra Pradesh. ${ }^{29}$ Members of the women's commission accepted this as a legitimate recommendation but viewed GM crop destruction as only one possible tactic among their proposals to protect people and the land. Unlike GM protests in countries where citizens feel their government has left them no choice but to destroy transgenic crops ${ }^{30}$ the farmer-jurors understood that the

\footnotetext{
${ }^{28}$ See footage from the video film Senekelaw Ka Kuma. Paroles de Paysans-from 17.15 to $18.00 \mathrm{~min}$. https://youtu.be/-4E2LGNneBQ Accessed 15 October 2020.

${ }^{29}$ See footnote 26.

${ }^{30}$ Specialist witness Guy Kastler described how GM protests and crop destruction in France was a direct citizens' response to top down government decisions to accelerate uptake of GMOs in industrial food and farming. See footage from the video film Senekelaw $\mathrm{Ka}$ Kuma. Paroles de Paysans-from 39.17 to $40.10 \mathrm{~min}$. https://youtu. be/-4E2LGNneBQ. Accessed 5 March 2021.
} 
Malian context was different and more fluid. Moreover, as the women further discussed and critically reflected on the pros and cons of burning GM crops, they made it clear that this threat was a persuasive device necessary to get the attention of the Malian government. For the women's commission, this rhetorical threat was part of an experience-based communication strategy aimed at insensitive bureaucrats and decision-makers who usually need to be pushed out of their comfort zone to listen to women farmers. Taken as a whole however, the women's commission was overwhelmingly committed to non-violence and the protection of life.

By affirming the defence of life and a regenerative agency, the women's recommendations reflect what Ariel Salleh has described as an'embodied materialist epistemology' (Salleh 2009) based on the day to day experience of negotiating humanity-nature relations. Throughout their deliberations, the women were indeed keen to fit the economic activity of farming inside a sustainable ecological framework whilst ensuring that their own reproductive labour and the use values they generate are fully recognised.

Notably, the ECID allowed farmer-jurors to grasp important underlying principles that are fundamental for the performance of GM crops in different environments. Deep insights were gained when a specialist witness described research showing how unstable genetically modified potatoes can be when grown in different conditions. For example, in temperature stressed environments the same transgenic potato variety produced its tubers above ground ('in the air') rather than in the soil. ${ }^{31}$ During their palavers and deliberations, farmers concluded that the characteristics of GM crops are likely to be unstable and-crucially-that scientists cannot really predict how GM crops will behave over time and space. ${ }^{32}$ This new awareness heightened their concerns that GM cotton oil might be altered and unsafe for human consumption. In their palavers, several farmers opined and anticipated that GM cotton would run into problems because

\footnotetext{
31 Dr Pia Malnoe described her experiments on transgenic potatoes in Switzerland, highlighting how gene-environment interactions caused GM potatoes to have unintended and abnormal growth patterns. See footage from the video film Senekelaw Ka Kuma. Paroles de Paysans-from 18.17 to $19.15 \mathrm{~min}$. https://youtu.be/-4E2LG NneBQ. Accessed 15 October 2020.

32 Recent scientific research shows that most traits of agricultural importance are multigenic and highly responsive to the environment, with change occurring rapidly in time and across different environments (Heinemann, 2020). Due to the imprecise nature of genetic engineering techniques, GM crops have met with an array of unintended adverse effects, including widespread mutations, altered nutritional profiles, and agronomic problems such as stunted growth or environmental disturbance of traits. Unintended changes that alter the expression of genes and affect a plant's metabolism and phenotype may have harmless or adverse impacts on human health or the environment, depending on the change(s) introduced (Eckerstorfer et al. 2019).
}

of unintended changes in the genetically engineered crop. This did indeed eventually happen in neighbouring Burkina Faso where, contrary to all expectations, the inferior lint quality of GM cotton led the government to completely phase out the cultivation of GM cotton in 2016. Major economic losses were incurred because Bt cotton had a lower ginning ratio and shorter fibre length than conventional Burkinabe cotton varieties (Dowd-Uribe and Schnurr 2016; Luna and Dowd-Uribe 2020).

Overall, the different perspectives of men and women farmers affirmed their right to food sovereignty. One of their primary concerns was to prevent dependence on multinational seed corporations and to protect local economies from dumping. As Brahim put it: "We want to be the masters of our own fields, not slaves."

Men and women farmers agreed with Amadou when he said: "GMOs will make us dependent on foreign corporations and this will cause despair. A farmer without hope is lost and helpless".

Concerns about the deeper cultural and social implications of large-scale use of GMOs were uppermost in discussions during the ECID of Sikasso. For example, farmerjurors used with some anxiety and disquiet the Bambara expression for GMOs: Bayere ma'shi ("transformed mother"). In a country like Mali, where animism remains alive beneath a veneer of Islam, genetic engineering - transferring genes from one species to another-is alarming and not compatible with widely held spiritual beliefs.

Similarly, GMOs were deemed an important threat to a co-operative way of life in Malian villages: "Our farmers are used to helping each other. The danger is that GMOs will destroy that sense of friendship and solidarity. It will be the end of mutual aid and compassion, and there will therefore be no more humanity in our villages". Birama.

Anger was expressed by some farmer-jurors when thinking about the kind of society their children would have to live in: "If the government forces us to grow GMOs, why should we not rebel against its decision? If we do not fight now what kind of future will our children have? This is the boubou $^{33}$ of slavery which is being crafted to put around the necks of our children". Alihou.

\footnotetext{
33 A boubou is a type of clothing worn in West Africa.
} 
As the chair of the Oversight Panel said in his final reflections on the ECID of Sikasso:

"This is not about simply deciding if we are for or against GMOs. Instead, the centrally important issue is to understand what kind of society is behind GMOs, and what are the future implications of this societal choice". Ousmane Sy.

The dominance of the scientific knowledge supporting industrial farming was thus challenged in the safe space created by the ECID. The latter enabled the articulation of farmer knowledge and alternative subaltern perspectives which broadened the debate. Through their palaver style deliberations, the farmer jurors had the capacity and freedom to shape "the boundaries that define for them the field of what is possible" (Hayward 1998, p. 12).

The holistic quality of the producers' analysis is particularly noteworthy. Farmers not only located their assessments of GM cotton within their overall place-based livelihood context. They also showed a clear understanding of how cultural and economic processes might intersect in a dynamic of agrarian change driven by the adoption of GM cotton. For example, farmers' concerns about cultural and spiritual change induced by the adoption of GM seeds as Bayere ma'shi ("transformed mother") intersected with economic concerns about the high cost of GM seeds and growing inequities in their villages. This transdisciplinary analytical framing compares well with the more reductionist frameworks of many conventional researchers (Pimbert 2018b). As Luna points out in her work on GM cotton adoption in Burkina Faso "few scholars have explicitly explored how economic and cultural processes intersect within processes of agrarian change to drive technology adoption" (Luna 2020, p. 450).

\section{Impacts on policy}

The outcomes of the ECID were widely reported by national and international media as soon as the farmer-jurors presented their recommendations to the Regional Assembly of Sikasso in a public event on $29^{\text {th }}$ January 2006. In the months that followed, we worked with the Steering Committee to facilitate an action research process that led to a series of national policy dialogues to share and discuss the ECID's recommendations (Online Appendix, Box A). Highprofile events took place in the capital city of Bamako in May-July 2006:
- Policy dialogue with the High Council of Regional Governments of Mali (Haut Conseil des Collectivités Locales) - held at the request of the President of the Regional Assembly of Sikasso to discuss all the ECID's recommendations.

- Public workshop to discuss the ECID's policy recommendations on GM cotton and the future of farming in Mali. Four farmer-jurors mandated by their peers presented and defended the ECID's recommendations in an assembly of over two hundred people, including government officials, civil society, peasant organisations, academia, international donors, and media.

Both events were widely reported in the media and this undoubtedly further enhanced the ECID's societal impact. Widespread concerns expressed by farmer organisations and other Malian citizens' prompted a three-hour debate in the National Assembly (Assemblée Nationale du Mali) on all of the ECID's policy recommendations, with deputies questioning the Minister of Agriculture on GMOs and research priorities. $^{34}$

The ECID caused the Malian government to indefinitely delay the approval of legislation that needed to be in place before GM crops can be introduced in the field. An external impact assessment ${ }^{35}$ showed that actors with major vested interests in GM technology were destabilised and frustrated by the ECID's recommendations (Bryant 2009). The coordinator of International Biosafety in the Ministry of Environment lamented: "Everyone is pointing at this Citizens' Jury in Sikasso.... The impact (of l'ECID) has been very negative... Here (in Mali) things are stalling because of the misinformation made worse by the jury" (Bryant 2009). Specialist witness Dr Dembelé as well as public and private sector scientists involved in GM research were also frustrated with this policy outcome, and they cast doubt on the judgment of the farmer-jurors. They did this in a manner that was consistent with how several scientists reacted to participatory risk assessments and public criticism of GMOs in Europe (Baumann and Pimbert 1998; Joly and Rip 2007; Levidow and Carr 2009). As scientists they questionedpost-ECID—-the legitimacy of this participatory process in

\footnotetext{
34 The debate in the National Assembly took place on 1st June 2006 at the request of the deputy Mr. Aboubacar Touré, the elected deputy from Niono and member of the National Commission on Rural Development and the Environment.

35 This independent external assessment was done by Peter Bryant with the permission of the ECID's Executive Committee. Although his visit to Mali was of relatively short duration, Bryant was able to capitalize on all the previous work done by the organisers of the ECID. He conducted interviews with key stakeholders over a month period in June-July 2006. Bryant's independent impact assessment supports our own findings and vice versa.
} 
relation to standard positivist forms of knowledge production and validation - a pattern commonly observed elsewhere (Ancori 2012). Our interviews with scientists also revealed a strong belief that "it is unthinkable that actors other than researchers should have the legitimacy to ask the right questions" (Kuhn et al. 1990, p. 24). More generally, it was apparent that the idea co-producing post-normal knowledge for democratic policy-making was a "nightmare for the scientific community" (Graur 2007, p. 1156).

Commenting in the UK's Independent, the West Africa regulatory manager for Monsanto said: "We cannot go into a country unless there are clear biotech regulations, covering matters of biosafety, and of how trials should be conducted and presented. Mali has none of these" (Selva 2006). The impact of the ECID was such that Monsanto radically changed its strategy: it decided to exit from Mali to consolidate its research and its investment efforts in neighbouring Burkina Faso. Researchers in Burkina Faso and Monsanto had indeed been working together before 2006, and the first field trials of Bt cotton in Burkina Faso were done in 2003 (Luna and Dowd-Uribe 2020). With the enactment of Burkina Faso's biosafety law in 2006, the policy environment became more enabling for GM cotton research and cultivation.

Thanks to the ECID, peasant organisations realised how much biosafety regulatory systems are a key determinant for the introduction and deployment of genetically modified organisms. It is noteworthy that a newly formed Government of Mali signed a National Biotechnology Security Law on December 1, 2008. ${ }^{36}$ However, lack of implementation regulations for this Biotechnology Security Law has continued to significantly constrain and limit agricultural research on GMOs in Mali. Most notably, the roll out of such national 'implementation legislation' has been systematically blocked by Malian members of La Via Campesina and social movements in West Africa. Emboldened by the outcomes of the ECID of Sikasso, the CNOP has actively mobilised farmers in the countryside against the introduction of GM crops in Mali, and continues to thwart the introduction of implementation regulations today (INFOGM 2008; CNOP 2020). Peasant organisations have thus greatly hampered the introduction of functional legislation for GM crops in Mali, and this has led to the "development of highly precautionary legislation .... and a cautious approach to adoption of GMOs" (Wafula et al. 2012, p. 76).

\footnotetext{
${ }^{36}$ Law n ${ }^{\circ} 08-042 / \mathrm{AN}-\mathrm{RM}, 1$ December 2008. Loi Relative à la Sécurité en Biotechnologie en République du Mali, Assemblée Nationale. Republic of Mali.
}

\section{Learning to do better next time}

We do not claim that the ECID was a flawless process. With the benefit of hindsight, we would particularly want to avoid two problems in future mini-publics on politically sensitive topics:

\section{Undermining subaltern voices}

Several high-profile figures in global social movements intervened to discredit and stop the ECID $48 \mathrm{~h}$ before its opening ceremony in Sikasso. A group of radical intellectuals and international peasant leaders who had just gathered in Bamako for the January 2006 World Social Forum were convinced that the ECID was controlled by Syngenta. These actors openly claimed that the organisers were in favour of GM technology and had close links with the corporate seed industry. They asked all invited specialist witnesses from civil society to sabotage ${ }^{37}$ and boycott the ECID. We were deeply destabilised when told that a delegation of well-known alter-globalisation activists and French peasant leaders would travel to Sikasso to denounce the ECID as a manipulative pro-industry event during the opening press conference. Nine months of preparatory work for the ECID were about to be jeopardised, in a highly public way. Through intense dialogues - and with the supportive intervention of civil society and peasant leaders ${ }^{38}$ from $L a$ Via Campesina-this act of sabotage was prevented only a few hours before the opening ceremony. We realise now that this dramatic situation could have been avoided had we made more efforts early on to reassure potential detractors about the independence of the ECID. This observation is also valid for pro-GM actors: with more trust-building and reassurances Monsanto, Syngenta Foundation, DAGRIS and USAID might have agreed to participate in the ECID's hearings.

However, this episode also highlighted the unwillingness of emblematic leaders and organisations to trust 'ordinary' farmers to make sensible decisions about politically sensitive issues. Our interviews show that some peasant leaders feared that the ECID's farmer-jurors would come out in favour of GM cotton because they do not really understand the complexities involved. They essentially viewed farmers as having a knowledge deficit which needed to be filled with

\footnotetext{
37 The word 'sabotage' was brandished by the international actors intent on disrupting the ECID of Sikasso. We have therefore chosen to use this word here because it accurately describes the destabilising threat we were faced with.

${ }^{38}$ Members of La Via Campesina who participated in the ECID, including the specialist witness Guy Kastler from the Réseau Semences Paysannes and the Confédération Paysanne in France, greatly helped to defuse this explosive situation and dispel misunderstandings.
} 
expert knowledge-in this case by their own knowledge as peasant leaders. This bias against peoples' knowledge and their capacity to decide for themselves through reasoned debate is commonplace and widespread among 'experts' and individuals in positions of authority (Dryzek 2010; Testart 2015).

Evidence suggests that changing this elitist and patronising mind-set can, in some cases, be encouraged through awareness raising and experiential education targeted at individuals invited to participate in future mini-publics. For example when we asked if he had learnt anything from his involvement in the ECID, a leader of a farmer organisation and specialist witness stated: "One thing I discovered was that before going I thought I knew everything in the rural world because I am an intellectual and a farmer; but I realised that the truth is with the people who deal with farming. It has been a humbling truth-I learnt a lot from this process and I realised I didn't know anything. The people who know are the farmers and they've never been to school".

\section{Lack of specialist witnesses with gendered perspectives on GMOs}

Four out of fourteen specialist witnesses were women-two Indian farmers and two internationally known scientists whose distinct perspectives enriched the ECID's deliberations (Online Appendix, Box E). However, we were unable to invite specialist witnesses who could speak about the gendered impacts of GM crops on social relations, household nutrition, and the work load of women farmers. The widespread institutional discrimination that marginalises gender studies and prevents many women from making a career in universities and research institutes (Goetz 1997; Winchester and Browning 2015; De Angelis and Grüning 2020) limited our options to invite suitable witnesses. Inviting more women scholars to give gendered evidence should nevertheless be a priority in future mini-publics on GM crops in West Africa-especially because recent research in Burkina Faso has shown that gendered labour dynamics and decision-making are affected by GM cotton cultivation (Luna 2020).

\section{Conclusion}

This paper has offered critical reflections on the methodology, process, and immediate outcomes of the Citizen Space for Democratic Deliberation (ECID) on GMOs and the future of farming in Mali. This unprecedented event in West Africa successfully mobilised a large number of farmers and other citizens in a bottom-up participatory process that clearly had an impact on policy and practice. The ECID helped politicise an issue of global importance and allowed marginalised voices to question the dominant discourse in favour of GM crops and the industrialisation of agriculture. As an experiment in deliberative democracy and action research, the ECID also helped to shift the focus of quality and validity from "a concern with idealist questions in search of truth to concern for engagement, dialogue, pragmatic outcomes, and an emergent reflexive sense of what is important" (Bradbury and Reason 2001, p. 343).

The African palaver model of social interaction and consensus-building (Hampate Ba 1985; Diangitukwa 2014) was given a new political legitimacy in the context of the ECID of Sikasso. Rooted in traditional Black African democratic practice, the ECID palavers and deliberations helped mediate a respectful dialogue between different knowledge systems and a search for the common good. This powerequalizing process was grounded in an emancipatory ethos and practice that fostered the creation of valuable knowledge by affirming the right to cognitive justice: "the constitutional right of different systems of knowledge to exist as part of a dialogue and debate" (Visvanathan 2005, p. 92). As such, this unique deliberative process helped change the traditional role of passive citizens to that of "builders of collective community knowledge and generators of policy change" (Evans-Agnew and Eberhardt 2019, p. 358). Moreover, this first ECID palaver is internationally significant because it de facto questions the unconscious racist biases (Tate and Page 2018) responsible for the relative absence of Black African mini-publics in contemporary practice and academic writing on deliberative democracy (Diangitukwa 2014).

As a safe space for communication and action, the ECID of Sikasso allowed farmer-citizens "to criticize power or withhold consent" (Chambers 2010, p. 896). The independent oversight panel concluded that legitimate decision-making was derived through consensus after public deliberation and respectful inclusion in the fair setting of the ECID, and without any coercive influences. However, from the perspective of deliberative democratic theory (Dryzek, 1990; Smith 2009; Parkinson and Mansbridge 2014; Bächtiger et al. 2017; Lafont 2019), we do not claim that the ECID was an 'ideal speech situation' (sensu Habermas 1996). Following Dryzek (1990) and Rostbøll (2009), we recognize that Habermas' 'ideal speech situation' can never be fully realized in practice. Rather than a perfect blueprint it is an imagined ideal that fundamentally "entails the inclusive and egalitarian dimension" of deliberative democracy (Rostbøll 2009, p. 21).

As a bottom-up participatory process, the ECID of Sikasso offers important insights on how to reverse the current democratic deficit in policy-making and risk assessments. Decisions about GM technology in the context of food, farming, and the environment require meaningful inclusive communication and engagement with, for, and by actors directly affected by these policy choices. This calls 
for methodological and institutional innovations which focus on enabling the early and ongoing engagement of different actors potentially affected by the policy decisions. It also requires robust safeguards to ensure that the debate is not just done on science's terms or framed by powerful actors with vested interests in GM seeds and new gene-drive technologies (Montenegro de Wit 2020; Wirz et al. 2020). In a context of uncertainty where genetic engineering is deeply contested, the ECID represents an internationally relevant transdisciplinary space where farmer and citizen knowledges can engage in safe conversations with the expertise of natural and social scientists to generate post-normal (sensu Ravetz 2006) forms of collective intelligence for policy making. When they do enable a deliberative democratic political culture-rather than just focus on supposedly "ideal deliberative designs" (Böker 2017, p. 18)—ECIDs can indeed generate informed citizen-led critique and proposals that break from any "heteronomously predetermined role" (Chambers 2013, p. 147). ECIDs and similar mini-publics can thus help disrupt authoritative decision-making and discourses on genetically engineered technologies, corporate control, and the broader project of the Fourth Industrial Revolution in food and agriculture (WEF 2018; Ndung'u and Signé 2020; Canfield et al. 2021).

Many people in West Africa say that the methodology and participatory policy process enabled by the ECID of Sikasso continue to have an enduring impact and relevance today-15 years later. For example in 2010, the ECID process was emulated in large-scale citizens' deliberations on the governance of agricultural research in West Africa (Pimbert et al. 2011). This West African process evolved into what Hendriks (2006) has called an "integrated deliberative system". The ECID of Sikasso together with two other interdependent ECIDs and a high-level policy dialogue with AGRA (IIED et al. 2012) were embedded in long-term and iterative PAR cycles in which there were multi-dimensional and multi-directional relationships with other actors in society as well as relationships with governments - from local to global. Actors who would not normally engage with each other interacted in new ways, and repeatedly. Cumulatively, this multi-actor deliberative process generated a political culture and impacts at local, national, regional, and international levels. Just in 2019, farmer and citizen groups identified the ECID methodology and its political culture as the best means of facilitating a public debate on the risks and benefits of Target Malaria's ${ }^{39}$ plans to introduce genetically

\footnotetext{
39 Target Malaria is a research consortium that aims to develop and share new genetic technologies to modify mosquitoes and reduce malaria transmission. The consortium plans to release genetically male sterile mosquitoes in parts of Africa, including Burkina Faso and Mali. Target Malaria receives core funding from the Bill \& Melinda Gates Foundation and from the Open Philanthropy Project Fund. See https://targetmalaria.org. Accessed 24 January 2020.
}

male sterile mosquitoes to combat malaria in Burkina Faso and Mali. Last but not least, several Malian peasant leaders ${ }^{40}$ have recently acknowledged the decisive positive impacts which the ECID of Sikasso has had on the self-pride of peasant farmers and on the determination of their organisations to struggle for agroecology and food sovereignty. This collective resolve of peasant organisations partly explains why AGRA has been unable to influence agricultural policies in Mali as much as it has in other parts of Africa (Goita 2020; Wise 2020). The ECID continues to motivate farmer-led efforts to claim peoples' sovereign right to define their own food and agricultural policies in Mali.

We close with this view of the Chair of the Oversight Panel:

"Until now, debates on major policy choices in Mali have been instigated and led by the State. In this sense, the ECID is a first. The fact that it was the Sikasso Regional Assembly and producer organisations that took the initiative bodes well for the future. The success of the exercise proves that decentralised communities and producers are capable of contributing to public policy decisions". Ousmane Sy.

Supplementary Information The online version contains supplementary material available at https://doi.org/10.1007/s10460-021-10221-1.

Acknowledgements Our sincerest gratitude goes to the farmers and other individuals who have shared their stories with us. We also thank the Dutch Ministry of Foreign Affairs (DGIS) and the Swiss Agency for Development and Cooperation (SDC) for funding this action research. We thank five anonymous AHUM reviewers for their very helpful comments and suggestions.

\section{Declarations}

Conflict of interest The authors declare no conflict of interest.

Consent to participate Interviewees and participants of the ECID gave their free prior informed consent before participating in the study.

Consent for publication Farmer participants agreed to the anonymous publication of their comments (they are identified by their first name to respect their privacy in this article). Other interviewees and participants made their statements freely available in writing and audio recordings.

Open Access This article is licensed under a Creative Commons Attribution 4.0 International License, which permits use, sharing, adaptation, distribution and reproduction in any medium or format, as long as you give appropriate credit to the original author(s) and the source, provide a link to the Creative Commons licence, and indicate if changes were made. The images or other third party material in this article are included in the article's Creative Commons licence, unless indicated

\footnotetext{
${ }^{40}$ For example, Ibrahima Coulibaly who is President of ROPPA (the Network of Peasant Organisations and Agricultural Producers in West Africa) shared this observation in interviews with authors on 22 January 2020.
} 
otherwise in a credit line to the material. If material is not included in the article's Creative Commons licence and your intended use is not permitted by statutory regulation or exceeds the permitted use, you will need to obtain permission directly from the copyright holder. To view a copy of this licence, visit http://creativecommons.org/licenses/by/4.0/.

\section{References}

Aasen, M., and A. Vatn. 2013. Deliberation on GMOs: A study of how a citizens' jury affects the citizens' attitudes. Environmental Values 22 (4): 461-481.

Agrilinks. 2020. The fourth industrial revolution and its potential applications in agriculture in Africa. https://www.agrilinks.org/ post/fourth-industrial-revolution-and-its-potential-applicationsagriculture-africa. Accessed 2 September 2020.

Alliance for a Green Revolution in Africa (AGRA). 2020. AGRA in 2019: Transforming African agriculture through partnerships. Nairobi: Alliance for a Green Revolution in Africa (AGRA).

Ancori, B. 2012. La production et la circulation des connaissances scientifiques et des savoirs profanes dans nos sociétés techniciennes. In: Darbellay F (ed.) La circulation des savoirs: Interdisciplinarité, concepts nomades, analogies, métaphores. Bern: Editions Internationales Peter Lang.

ARdS (Assemblée Régionale de Sikasso). 2005. OGM et débat citoyen. Policy dialogue on 27 et 28 June 2005. Ministère de l'Administration Territoriale et des Collectivités Locales, Assemblée Régionale de Sikasso, Mali.

ARdS (Assemblée Régionale de Sikasso). 2006. Rapport général. Espace Citoyen d'Interpellation Démocratique (ECID) sue les Organismes Génétiquement Modifiés (OGM) en relation avec l'avenir de l'agriculture au Mali. Ministère de l'Administration Territoriale et des Collectivités Locales, Assemblée Régionale de Sikasso, Mali.

Bächtiger, A., J.S. Dryzek, J.J. Mansbridge, and M. Warren. 2017. Oxford handbook of deliberative democracy. Oxford: Oxford University Press.

Baumann, M. and M.P. Pimbert. 1998. The people versus the life industry. Seedling (March), GRAIN. https://www.grain.org/en/article/ 294-the-people-versus-the-life-industry. Accessed 23 February 2021.

Benessia, A., S. Funtowicz, M. Giampietro, Â. Guimaraẽs Pereira, J. Ravetz, A. Saltelli, R. Strand and J.P. van der Sluijs. 2016. The rightful place of science: Science on the verge. Tempe, AZ: Consortium for Science, Policy \& Outcomes.

Bhambra, G. 2014a. Introduction: Knowledge production in global context: Power and coloniality. Current Sociology 62 (4): 451-456. https://doi.org/10.1177/0011392114524504.

Bhambra, G.K. 2014b. Postcolonial and decolonial dialogues. Postcolonial Studies 17 (2): 115-121. https://doi.org/10.1080/13688 790.2014.966414.

Bhattacharya, T. 2017. Social Reproduction Theory: Remapping class, recentering oppression. London: Pluto Press.

Böker, M. 2017. Justification, critique and deliberative legitimacy: The limits of mini-publics. Contemporary Political Theory 16 (1): $19-40$.

Bradbury, H., and P. Reason. 2001. Broadening the bandwidth of validity: Issues and choice points for improving the quality of action research. In Handbook of action research: Participative inquiry and practice, ed. P. Reason and H. Bradbury. London: SAGE Publishing.

Bradley, K., and H. Herrera. 2016. Decolonizing food justice: Naming, resisting, and researching colonizing forces in the movement. Antipode 48 (1): 97-114. https://doi.org/10.1111/anti.12165.
Bryant, P. 2009. Deliberative governance: political fad or a vision of empowerment? In , ed. C. Lyall, T. Papaioannou, and J. Smith. Burlington: Ashgate.

CAGJ/AGRA Watch. 2020. The struggle over agroecology: Mapping and mobilizing against the gates foundation's influence in African agriculture. Community Alliance for Global Justice/AGRA Watch. Webinar video and transcript at https://cagj.org/2020/08/ watch-the-agra-watch-webinar-the-struggle-over-agroecology/. Accessed 31 August 2020.

Canfield, M., M.D. Anderson, and P. McMichael. 2021. UN Food Systems Summit 2021: Dismantling democracy and resetting corporate control of food systems. Frontiers in Sustainable Food Systems 5: 661552. https://doi.org/10.3389/fsufs.2021.661552.

Campbell, D.J., and J. Crittenden. 2019. Direct deliberative democracy: How citizens can rule. Montreal: Black Rose Books.

Centre Djoliba. 2003. Actes de l'Espace Communal d'Interpellation Democratique (ECID), Sikasso $16^{\text {th }}-19^{\text {th }}$ December 2003. Bamako: Association DJOLIBA Hommes et Développement.

Chambers, S.A. 2010. Theories of political justification. Philosophy Compass 5 (11): 893-903.

Chambers, S.A. 2013. The lessons of Rancière. Oxford: Oxford University Press.

CMDT. 2008. Statement of Mali at the 67th plenary meeting of the ICAC. Ouagadougou: Republic of Mali, Office of the Prime Minister.

Community Media Trust, P.V. Satheesh and M.P. Pimbert. 2008. Affirming Life and Diversity: Rural Images and Voices on Food Sovereignty in South India. Reclaiming Diversity and Citizenship Series. London: IIED. https://pubs.iied.org/sites/default/ files/pdfs/migrate/14556IIED.pdf. Accessed 17 February 2021.

Cooper, M.W., and C.T. West. 2016. Unravelling the Sikasso Paradox. Agricultural change and malnutrition in Sikasso, Mali. Ecology of Food and Nutrition 56 (2): 1-23.

Coote, A., and J. Lenaghan. 1997. Citizens' Juries: Theory into practice. London: IPPR.

Cornwall, A. 2004. Introduction: New democratic spaces? The politics and dynamics of institutionalised participation. IDS Bulletin 35 (2): $1-10$.

Cornwall, A., and V.S. Coelho. 2006. Spaces for Change? The politics of citizen participation in new democratic arenas. London: Zed Books.

Crenshaw, K. 1991. Mapping the margins: Intersectionality, identity politics, and violence against women of color. Stanford Law Review 43 (6): 1241-1299. https://doi.org/10.2307/1229039.

De Angelis, G., and B. Grüning. 2020. Gender inequality in precarious academic work: Female adjunct professors in Italy. Frontiers in Sociology 4: 87. https://doi.org/10.3389/fsoc.2019.00087.

Delannoi, G. 2019. Le Tirage au sort. Comment l'utiliser. Paris: Presses de Sciences Po.

de Sousa, S.B. 2008. Introduction: Opening up the canon of knowledge and recognition of difference. In Another knowledge is possible: Beyond northern epistemologies: Vol. Reinventing social emancipation, ed. S.B. de Santos. London: Verso.

de Sousa, S.B. 2015. Epistemologies of the South: Justice against Epistemicide. New York: Routledge.

Diangitukwa, F. 2014. The distant origin of African Governance: The Palaver Tree. Revue Gouvernance. https://doi.org/10.7202/10388 81 ar.

Diawara, M., M. Harvard, M. Soumare, A. Keita, A. Traore, and B. Kone. 2019. Typology des exploitations agricoles pour l'accompagnement des producteurs dans les zones cotonnieres du Mali. In: Les zones cotonnières africaines: Dynamiques et durabilité, eds S. Mamy and M. Havard, 157-172. Actes du colloque de Bamako, 21 au 23 Novembre 2017. Bamako. Montpellier: Cirad-Agritrop. 
Dowd-Uribe, B. 2014. Engineering yields and inequality? How institutions and agro-ecology shape Bt cotton outcomes in Burkina Faso. Geoforum 53: 161-171.

Dowd-Uribe, B., and M.A. Schnurr. 2016. Burkina Faso's reversal on genetically modified cotton and the implications for Africa. African Affairs 115 (458): 161-172.

Dryzek, J.S. 1990. Discursive Democracy. Politics, Policy, and Political Science. Cambridge: Cambridge University Press.

Dryzek, J.S. 2000. Deliberative democracy and beyond. Oxford: Oxford University Press.

Dryzek, J.S. 2010. Foundations and frontiers of deliberative governance. Oxford: Oxford University Press.

Dryzek, J.S., and A. Tucker. 2008. Deliberative innovation to different effect: Consensus conferences in Denmark, France, and the United States. Public Administration Review 68 (5): 864-876.

Dussel, E. 1993. Eurocentrism and modernity. Boundary 2: an International Journal of Literature and Culture 20 (3): 65-76.

Eckerstorfer, M.F., M. Dolezel, A. Heissenberger, M. Miklau, W. Reichenbecher, R.A. Steinbrecher, and F. Waßmann. 2019. An EU perspective on biosafety considerations for plants developed by genome editing and other new genetic modification techniques (nGMs). Frontiers in Bioengineering and Biotechnology 7: 31. https://doi.org/10.3389/fbioe.2019.0003.

Elstub, S., and O. Escobar. 2019. Handbook of democratic innovation and governance. Cheltenham: Edward Elgar Publishing.

Evans-Agnew, R.A., and C. Eberhardt. 2019. Uniting action research and citizen science: Examining the opportunities for mutual benefit between two movements through a woodsmoke photovoice study. Action Research 17 (3): 357-377. https://doi.org/ $10.1177 / 1476750318798909$.

Ezeanya, C. 2011. Education and Indigenous Knowledge in Africa: Traditional bone setting and orthopaedic medicine in West Africa. Washington, DC: Howard University.

Fanon, F. 2021. Black Skin, White Masks. London: Penguin Modern Classics.

FAO. 2017. Mali Fact Sheet on Food and Agriculture Policy Trends. Rome: United Nations Food and Agriculture Organization.

FAO and IFAD. 2019. United Nations Decade of Family Farming 2019-2028. Global Action Plan. Rome: United Nations Food and Agriculture Organization.

Federici, S. 2012. Revolution at point zero: Housework, reproduction and feminist struggle. Oakland, CA: PM Press.

Fine, M., J.E. Tuck, and S. Zeller-Berkman. 2007. Do you believe in Geneva? In Handbook of critical and indigenous knowledges, ed. N. Denzin, L.T. Smith, and Y. Lincoln. Beverley Hills, CA: Sage.

Fishkin, J.S. 2011. When the people speak: Deliberative democracy and public consultation. Oxford: Oxford University Press.

Fishkin, J.S., and J. Mansbridge. 2017. The Prospects and limits of deliberative democracy. Dadalus, the Journal of the American Academy of Arts \& Sciences. https://doi.org/10.1162/ DAED_x_00442.

Flachs. A. 2019. Cultivating Knowledge. Biotechnology, Sustainability, and the Human Cost of Cotton Capitalism in India. Tucson: University of Arizona Press.

Forum pour l'Autre Mali. 2004. Fibre Africaine. Conclusions et propositions du Forum de la Societé Civile sur le Coton au Service de la Créativité et du Lien Social. Bamako, Mali.

Fung, A. 2003. Recipes for public spheres: Eight institutional design choices and their consequences. The Journal of Political Philosophy 11 (3): 338-367.

Funtowicz, S.O., and J.R. Ravetz. 1993. Science for the post-normal age. Futures 25 (7): 739-755.

Glover, D. 2010. The corporate shaping of GM crops as a technology for the poor. The Journal of Peasant Studies 37 (1): 67-90.
Goetz, A.M. 1997. Getting institutions right for women in development. London: Zed Books.

Goita, M. 2020. It's a vicious cycle. Interview on AGRA for the Rosa Luxemburg Foundation, Germany. https://www.rosalux.de/en/ news/id/42644?cHash $=\mathrm{c} 1516 \mathrm{e} 5 \mathrm{c} 7957 \mathrm{c} 0497 \mathrm{a} 09 \mathrm{c} 27027403 \mathrm{bc} 2$. Accessed 5 October 2020.

Goodin, R.E., and J.S. Dryzek. 2006. Deliberative impacts: the macro-political uptake of mini-publics. Politics \& Society 34 (2): 219-244.

GRAIN. 2004. Bt cotton on Mali's doorstep. Seedling, 18 Apr 2004. GRAIN, Barcelona.

Graur, D. 2007. Public control could be a nightmare for researchers. Nature 450 (1156): 20. https://doi.org/10.1038/4501156b.

Grönlund, K., A. Bachtiger and M. Setälä, 2015. Deliberative minipublics: Involving citizens in the democratic process. ECPR Press.

Grosfoguel, R. 2007. The epistemic decolonial turn: Beyond political-economy paradigms. Cultural Studies 21 (2-3): 211-223. https://doi.org/10.1080/09502380601162514.

Grosfoguel, R. 2011. Decolonizing post-colonial studies and paradigms of political economy: Transmodernity, decolonial thinking, and global coloniality. Transmodernity 1 (1): 214.

Grosfoguel, R. 2013. The structure of knowledge in Westernized universities: Epistemic racism/sexism and the four genocides/epistemicides of the long 16th century'. Human Architecture: Journal of the Sociology of Self-Knowledge 11 (1), 73-90. Online. http://scholarworks.umb.edu/humanarchitecture/vol11/iss1/8/. Accessed 29 October 2016.

Habermas, J. 1981. Theory of Communicative Action. Volume one: Reason and Rationalization of Society. Boston: Beacon Press.

Habermas, J. 1996. Between facts and norms. contributions to a discourse theory of law and democracy. Cambridge: Polity.

Hall, B.L., and R. Tandon. 2017. Decolonization of knowledge, epistemicide, participatory research and higher education'. Research for All 1 (1): 6-19. https://doi.org/10.18546/RFA.01.1.02.

Hampaté Ba, A. 1985. Lettre à la Jeunesse Africaine. In: Lettres ouvertes à la jeunesse-Concours Dialogue des générations. Agence de Coopération Culturelle et Technique. [Accessed on 5 October 2020 at Des Lettres-https://www.deslettres.fr/damad ou-hampate-ba-jeunesse-soyez-au-service-vie/].

Hayward, C.R. 1998. De-facing power. Polity 31 (1): 1-22.

Head, G. and T. Dennehy. 2010. Insect resistance management for transgenic Bt cotton. In Cotton Biotechnology in Agriculture and Forestry, 65, ed. U.B. Zehr. Berlin: Springer-Verlag. https://doi. org/10.1007/978-3-642-04796-1_7.

Heinemann, J.A. 2020. Assessment of modern biotechnologies. In: Transformation of our food system, ed. H. R. Herren, B. Haerlin and the IAASTD+10 Advisory Group. Zurich: Biovision and Foundation for Future Farming.

Hendriks, C.M. 2006. Integrated deliberation: reconciling civil society's dual role in deliberative democracy. Political Studies 54 (3): 486-508.

Heyzer, N. 1986. Working women in South-east Asia. Development, subordination and emancipation. London: Open University Press.

Hill Collins, P., and S. Bilge. 2020. Intersectionality. London: Polity Press.

Hooks, B. 2000. Feminist theory: From margin to center. London: Pluto Press.

Hugon, P. 2005. Les réformes de la filière coton au Mali et les négociations internationales. Afrique Contemporaine 216 (4): 203-225.

IIED, APPG on Agroecology, CNOP, Kene conseils, Centre Djoliba, and IRPAD, 2012. High level policy dialogue between the Alliance for a Green Revolution in Africa (AGRA) and small-scale farmers on the priorities and governance of agricultural research 
for development in West Africa. IIED, London. https://pubs.iied. org/G03349/. Accessed 18 February 2021.

INFOGM. 2008. Mali-L'adoption d'une loi sur les OGM mécontente les organisations paysannes. INFOGM, 13 November 2008. Paris. https://www.infogm.org/MALI-L-adoption-d-une-loi-surles?lang=fr. Accessed 8 February 2021.

Involve. 2020. Methods for public participation. https://www.involve. org.uk. Accessed 22 September 2020.

Irwin, A. 2001. Citizen engagement in science and technology policy: A commentary on recent UK experience. Participatory Learning and Action 40: 72-75.

James C. 2010. Global status of commercialized biotech/GM crops. ISAAA brief 42. Ithaca, NY: ISAAA.

Jasanoff, S. 2016. The ethics of invention: Technology and the human future. New York: Norton.

Jepson, P.C., M. Guzy, K. Blaustein, M. Sow, M. Sarr, P. Mineau, and S. Kegley. 2014. Measuring pesticide ecological and health risks in West African agriculture to establish an enabling environment for sustainable intensification. Philosophical Transactions of the Royal Society b: Biological Sciences 369: 20130491.

Joly, P.B., and A. Rip. 2007. A timely harvest. Nature 450: 174. https:// doi.org/10.1038/450174a.

Kelly, R., R. Pirog, A. Guel, J. Henderson, K. Wilcox, T. Wimberg, V. García Polanco, D. Babayode, K. Watson, and E. Nelson. 2020. An Annotated Bibliography on Structural Racism Present in the U.S. Food System, Seventh Edition. MI: MSU Center for Regional Food Systems (CRFS).

Kuhn T.S, M. Biezunski, P. Jacob et al. 1990. La tension essentielle. Tradition et changement dans les sciences. Paris: Gallimard.

Kuruganti, K., M.P. Pimbert, and T. Wakeford. 2008. The people's vision: UK and Indian reflections on Prajateerpu. Participatory Learning and Action 58: 11-17.

Lafont, C. 2019. Democracy without shortcuts: A participatory conception of deliberative democracy. Oxford: Oxford University Press.

Levidow, L., and S. Carr. 2009. GM food on trial: testing European DEMOCRACY. London: Routledge.

Levidow, L. 2008. Democratizing technology choices: European public participation in agbiotech assessments. Gatekeeper Series, No. 135. London: International Institute for Environment and Development.

Levkoe, C.Z., J. Brem-Wilson, and C.R. Anderson. 2018. People, power, change: Three pillars of a food sovereignty research praxis. The Journal of Peasant Studies 46 (7): 1389-1412. https://doi.org/10.1080/03066150.2018.1512488.

Lowder, S.K., J. Skoet, and T. Raney. 2016. The number, size, and distribution of farms, smallholder farms, and family farms worldwide. World Development 87: 16-29.

Luna, J.K. 2020. 'Pesticides are our children now': cultural change and the technological treadmill in the Burkina Faso cotton sector. Agriculture and Human Values 37: 449-462. https://doi.org/10. 1007/s10460-019-09999-y.

Luna, J.K., and B. Dowd-Uribe. 2020. Knowledge politics and the Bt cotton success narrative in Burkina Faso. World Development 136: 105127.

Luskin, R.C., I. O'Flynn, J.S. Fishkin, and D. Russell. 2014. Deliberating across deep divides. Political Studies 62 (1): 117.

Marks, S. and G. Paravicini. 2018. How Syngenta won the war over weed killers. Politico. 27 March 2018. https://www.politico.eu/ article/how-syngenta-swiss-agrichemical-avoided-weedkillerpesticide-ban-despite-safety-concerns-eu-commission/. Accessed 5 October 2020.

Martinez Palacios, J. 2016. Equality and diversity in democracy: How can we democratize inclusively? Equality, Diversity and Inclusion: an International Journal 35 (5/6): 350-363. https://doi.org/ 10.1108/EDI-04-2016-0030.
Mies, M. 2014. Patriarchy and accumulation on a world scale: Women in the international division of labour. London: Zed Books.

Mignolo, W.D. 2007. Delinking: The rhetoric of modernity, the logic of coloniality and the grammar of de-coloniality. Cultural Studies 21 (2-3): 449-514. https://doi.org/10.1080/09502380601162647.

Mignolo W. D. and C.E. Walsh. 2018. On decoloniality. Concepts, analytics, praxis. Durham: Duke University Press.

Mittal, A. and M. Moore. 2009. Voices from Africa. The Oakland Institute. https://www.oaklandinstitute.org/sites/oaklandinstitute.org/ files/voicesfromafrica_full.pdf. Accessed 18 February 2021.

Monsanto Tribunal. 2016. Human rights violations, crimes against humanity and ecocide, legal case prepared for The Monsanto Tribunal held on 15-16 October 2016, The Hague. https://www. monsanto-tribunal.org. Accessed 3 October 2020.

Montenegro de Wit, M. 2020. Democratizing CRISPR? Stories, practices, and politics of science and governance on the agricultural gene editing frontier. Elementa: Science of the Anthropocene. https://doi.org/10.1525/elementa.405.

Moseley, W.G. 2005. Global cotton and local environmental management: the political ecology of rich and poor farmers in southern Mali. Geography Journal 171: 36-55. https://doi.org/10.1111/j. 1475-4959.2005.00148.x.

Moseley, W.G., M.A. Schnurr, and R. Bezner Kerr. 2017. Africa's green revolution: Critical perspectives on new agricultural technologies and systems. New York: Routledge.

Ndung'u, N. and L. Signé. 2020. The Fourth Industrial Revolution and digitization will transform Africa into a global powerhouse. In: Foresight Africa: Top priorities for the continent 2020-2030. Washington DC: Brookings Institution.

Neajai Pailey, R. 2019. De-centring the 'White Gaze' of development. Development and Change 51 (3): 729-745. https://doi.org/10. 1111/dech.12550.

Ngugi, W.T. 1986. Decolonising the mind. The politics of language in African literature. Rochester: James Currey.

Nipon, A.R., M. DeGraeve, and W. Elsen. 2017. De la Françafrique à la corruption : les dessous de la filière coton au Burkina Faso. Basta Mag, 28 February 2017.

OECD. 2020. Innovative Citizen Participation and New Democratic Institutions: Catching the Deliberative Wave. Paris: OECD Publishing at https://doi.org/10.1787/339306da-en. Accessed 5 October 2020.

O'Flynn, I. 2007. Divided societies and deliberative democracy. British Journal of Political Science 37 (4): 731-751.

Parkinson, J. and J. Mansbridge. 2014. Deliberative Systems. Deliberative Democracy at the Large Scale. Cambridge: Cambridge University Press.

Patel, R. 2013. The long green revolution. Journal of Peasant Studies 40 (1): $1-63$.

Peeters, M.A. 2020. The African palaver tradition and the western postmodern consensus: convergences and divergences. Dialogue Dynamics. Institute for Intercultural Dialogue Dynamics http:// dialoguedynamics.com/content/forum-d-apprentissage/modul es/consensus-palabre/article/the-african-palaver-tradition-and. Accessed 25 September 2020.

People's Knowledge Editorial Collective (Eds). 2017. Everyday Experts: How people's knowledge can transform the food system. Reclaiming Diversity and Citizenship Series. Coventry: Coventry University. www.coventry.ac.uk/everyday-experts. Accessed 5 October 2020.

Pimbert, M.P. 2018a. Food sovereignty, agroecology and biocultural diversity: Constructing and contesting knowledge. London: Routledge.

Pimbert, M.P. 2018b. Democratizing knowledge and ways of knowing for food sovereignty, agroecology, and biocultural diversity. In Food sovereignty, agroecology and biocultural diversity: 
Constructing and contesting knowledge, ed. M.P. Pimbert, 259321. London: Routledge.

Pimbert, M. P. and Wakeford, T. 2001. Deliberative democracy and citizen empowerment. PLA Notes 40, IIED. Co-published by the Commonwealth Foundation, ActionAid, DFID, Sida and IIED, https://pubs.iied.org/6345IIED/?k=Pimbert+and+wakeford. Accessed 2 October 2020.

Pimbert, M.P. and T. Wakeford. 2002. 'Prajateerpu': food and farming futures for Andhra Pradesh. Economic and Political Weekly. 37(27): 2778-2787, https://www.epw.in/journal/2002/27/reviewscience-policy-review-issues-specials/prajateerpu-food-andfarming-futures.

Pimbert, M.P., and T. Wakeford. 2003. Prajateerpu, power and knowledge: The politics of participatory action research in development, Part 1: Context, process and safeguards'. Action Research 1 (2): 185-207. https://doi.org/10.1177/14767503030012004.

Pimbert, M.P., T. Wakeford, and P.V. Satheesh. 2003. Des petits paysans et des marginaux ruraux s'expriment sur l'agriculture et les OGM. La Revue Durable 6: 34-39.

Pimbert, M.P., B. Barry, A. Berson and K. Tran-Thanh. 2011. Democratising Agricultural Research for Food Sovereignty in West Africa, the International Institute for Environment and Development (IIED), the Coordination Nationale des Organizations Paysannes (CNOP), le Centre Djoliba, l'Institut de Recherche et de Promotion des Alternatives en Dévelppement (IRPAD), Kene Conseils, l'Union des Radios et Télévisions Libres du Mali (URTEL), Bamako and London. https://pubs.iied.org/sites/defau 1t/files/pdfs/migrate/14603IIED.pdf. Accessed 23 April 2021.

Pimbert, M.P., P. V. Satheesh, A. Argumedo and T. M. Farvar. 2017. Participatory action research transforming local food systems in India, Iran and Peru. In: Everyday Experts: How people's knowledge can transform the food system, Ed. People's Knowledge Editorial Collective, 99-118. Coventry: Coventry University Reclaiming Diversity and Citizenship Series. www.coventry.ac. uk/everyday-experts. Accessed 23 September 2020.

Pretty, J.N., I.M. Guijit, J. Thompson, and I. Scoones. 1995. Participatory action and learning: A trainer's guide. London: IIED.

Pio, O. 2007. Paris brade le coton subsaharien. Le Monde Diplomatique, September pp. 18-19.

Pray, C., J. Huang, R. Hu, and S. Rozelle. 2002. Five years of Bt cotton in China-The benefits continue. The Plant Journal 31: 423-430.

Purcell, J.P., and F.J. Perlak. 2004. Global impact of insect-resistant (Bt) cotton. AgBioforum 7 (1-2): 27-30.

Qaim, M., and D. Zilberman. 2003. Yield effects of genetically modified crops in developing countries. Science 299 (5608): 900-902.

Ravetz, J.R. 2006. The no-nonsense guide to science. Oxford: New Internationalist Publications.

Reason, P., and H. Bradbury. 2013. The SAGE handbook of action research: participative inquiry and practice, 2 nd ed. London: Sage Publications.

Republic of Mali. 2005. National biosafety framework project. Ministry of Environment and Sanitation of Mali. STP/CIGQE: Bamako.

Robert, A.C. 2006. L'Afrique au secours de l'Occident. Paris: Les éditions de l'Atelier.

Rock, J. 2018. "We are not starving:" challenging genetically modified seeds and development in Ghana. Culture, Agriculture, Food and Environment. 41 (1): 15-23.

Rostbøll, C.F. 2009. Dissent, criticism, and transformative political action in deliberative democracy. Critical Review of International Social and Political Philosophy 12 (1): 19-36.

Russell, G. 2018. Bill Gates at Edinburgh University to help fund GM crop research. The National. 26th January 2018 https://www. thenational.scot/news/15898513.bill-gates-edinburgh-universityhelp-fund-gm-crop-research/. Accessed 22 February 2021.
SAICM. 2019. Mali and Senegal communities monitoring pesticides. Strategic Approach to International Chemicals Management (SAICM). United Nations Environment Programme (UNEP). http://www.saicm.org/Resources/SAICMStories/MaliandSen egalcommunitiesmonitoringpesticides/tabid/5857/Default.aspx. Accessed on 15 November 2019.

Salas, M.A., H. J. Tillmann, N. McKee and N. Shahzadi. 2010. Visualisation in Participatory Programmes. How to Facilitate and Visualise Participatory Group Processes. Dhaka, Bangladesh: Southbound Press and UNICEF.

Salleh, A. 2009. Eco-sufficiency and global justice. Women write political ecology. London: Pluto Press.

Schnurr, M.A. 2015. GMO 2.0: Genetically modified crops and the push for Africa's green revolution. Canadian Food Studies 2 (2): 201-208.

Schnurr, M.A. 2019. Africa's gene revolution: Genetically modified crops and the future of African agriculture. Montreal: McGillQueen's University Press.

Schurman, R. 2016. Building an alliance for biotechnology in Africa. Journal of Agrarian Change 17 (3): 1-18.

Selva, M. 2006. Mali farmers reject GM crops as attack on their way of life. Independent at https://www.independent.co.uk/news/ world/africa/mali-farmers-reject-gm-crops-as-attack-on-theirway-of-life-5337122.html. Accessed 23 September 2020.

Sen, A. 2003. Why democratization is not the same as westernization: Democracy and its global roots. New Republic, 4 October: $28-36$.

Scheurich, J.J., and M.D. Young. 1997. Coloring epistemologies: Are our research epistemologies racially biased? Educational Researcher 26 (4): 4-16. https://doi.org/10.3102/0013189X02 6004004.

Schurman, R. 2017. Building an alliance for biotechnology in Africa. Journal of Agrarian Change 17 (3): 441-458.

Smith, G. 2009. Democratic innovations. Designing institutions for citizen participation. Cambridge: Cambridge University Press.

Squires, J. 2010. Beyond Multiple Inequalities: Transversal Intersectionality, Diversity Mainstreaming and Participative Democracy. Kvinder Køn Forskning. https://doi.org/10.7146/kkf.v0i2-3. 28017

Sundberg, J. 2017. Feminist Political Ecology. In: International Encyclopedia of Geography: People, the Earth, Environment and Technology. Eds. D. Richardson, N. Castree, M.F. Goodchild, A. Kobayashi, W. Liu and R.A. Marston. https://doi.org/10.1002/ 9781118786352.wbieg0804

Tabashnik, B.E., Y. Carrière, T.J. Dennehy, S. Morin, M.S. Sisterson, R.T. Roush, A.M. Shelton, and J.-Z. Zhao. 2003. Insect resistance to transgenic Bt crops: Lessons from the laboratory and field. Journal of Economic Entomology 96 (4): 1031-1038. https://doi.org/10.1603/0022-0493-96.4.1031.

Tate, S and D. Page. 2018. Whiteliness and institutional racism: Hiding behind (un)conscious bias. Ethics and Education, 13 (1) pp. 141-155. ISSN 1744-9642. https://doi.org/10.1080/17449642. 2018.1428718

Tefft, J. 2004. Building on successes in African agriculture: Mali's White Revolution: smallholder cotton from 1960 to 2003. 2020 Vision Focus 12(5). Washington, DC: International Food Policy Research Institute,. https://www.ifpri.org/publication/maliswhite-revolution-smallholder-cotton-1960-2003.

Testart, J. 2015. L'Humanitude au pouvoir, Comment les citoyens peuvent decider du bien commun. Paris: Seuil.

The New Humanitarian. 2008. Cooking with poison. 6 February 2008. https://www.thenewhumanitarian.org/report/76613/mali-cooki ng-poison. Accessed 8 October 2020.

Tuhiwai Smith, L. 2012. Decolonizing methodologies: Research and indigenous peoples. London: Zed Books. 
Tsan, M., S. Totapally, M. Hailu, and B.K. Addom. 2019. The Digitalisation of African Agriculture Report 2018-2019. Wageningen: CTA/Dalberg Advisers

UCS. 2017. Syngenta Harassed the Scientist Who Exposed Risks of Its Herbicide Atrazine. Union of Concerned Scientists (UCS), Washington DC. https://www.ucsusa.org/resources/syngentaharassed-scien- tist-who-exposed-risks-its-herbicide-atrazine. Accessed 22 February 2021

Visvanathan, S. 2005. Knowledge, justice and democracy. In: Science and Citizens: Globalization and the Challenge of Engagement, Eds. M. Leach, I. Scoones and B. Wynne, 83-94. London: Zed Books.

Wakeford, T. and Pimbert, M.P. 2003. Power-reversals in Biotechnology: Experiments in democratization, Brighton: Institute of Development Studies.

Wakeford, T., J. Singh, B. Murtuja, P. Bryant, and M.P. Pimbert. 2008. The jury is out: How far can participatory projects go towards reclaiming democracy? In The SAGE handbook of action research, ed. P. Reason and H. Bradbury, 333-349. London: Sage Publications. https://doi.org/10.4135/9781848607934

Wafula, D., M. Waithaka, J. Komen, and M. Karembu. 2012. Biosafety legislation and biotechnology development gains momentum in Africa. GM Crops \& Food 3 (1): 72-77.

Winchester, H.P.M., and L. Browning. 2015. Gender equality in academia: A critical reflection. Journal of Higher Education Policy and Management 37 (3): 269-281. https://doi.org/10.1080/13600 80X.2015.1034427.

Wironen, M.B., R. V. Bartlett and J. D. Erickson. 2019. Deliberation and the Promise of a Deeply Democratic Sustainability Transition. Sustainability. dhttps://doi.org/10.3390/su11041023

Wirz, C.D., D.A. Scheufele, and D. Brossard. 2020. Societal debates about emerging genetic technologies: Toward a science of public engagement. Environmental Communication 14 (7): 859-864. https://doi.org/10.1080/17524032.2020.1811478.

Wise, T.A. 2020. Failing Africa's Farmers: An Impact Assessment of the Alliance for a Green Revolution in Africa. Global Development and Environment Institute, Working Paper No 20.01, Tufts University.
WEF, 2018. Innovation with a Purpose: The role of technology innovation in accelerating food systems transformation. Geneva: World Economic Forum.

Yárnoz, I. 2020. Conflict and conflict resolutions in Africa. The future of United Nations Multidimensional Integrated Stabilization Mission in Mali (MINUSM). Global Affairs and Strategic Studies. Universidad de Navarra. https://www.unav.edu/web/globalaffairs/detalle/-/blogs/conflict-and-conflict-resolutions-in-africathe-future-of-united-nations-multidimensional-integrated-stabi lization-mission-in-mali-minusma-. Accessed 2 September 2020

Young, I.M. 1986. The ideal of community and the politics of difference. Social Theory and Practice 12 (1): 1-26.

Publisher's Note Springer Nature remains neutral with regard to jurisdictional claims in published maps and institutional affiliations.

Michel P. Pimbert is Professor of Agroecology and Food Politics and the Director of the Centre for Agroecology, Water and Resilience at Coventry University (UK). His research interests include agroecology and food sovereignty; the political ecology of biodiversity and natural resource management; participatory action research methodologies; and deliberative democratic processes. He works with networks of small and family farmers, indigenous peoples, and4communities to advance transdisciplinary and transformative ways of knowing that regenerate local ecologies, economies and cultural diversity.

Boukary Barry is a development professional actively engaged in critical reflection and analysis of development models. He collaborates with research and training institutes as well as development aid agencies, including the Swiss Agency for Development and Cooperation, and the universities of Geneva and Coventry. Through trainings and long-term participatory processes, he has helped strengthen small-scale producer organisations in West Africa. 